\title{
Effects of Acid Rain on Soil and Water
}

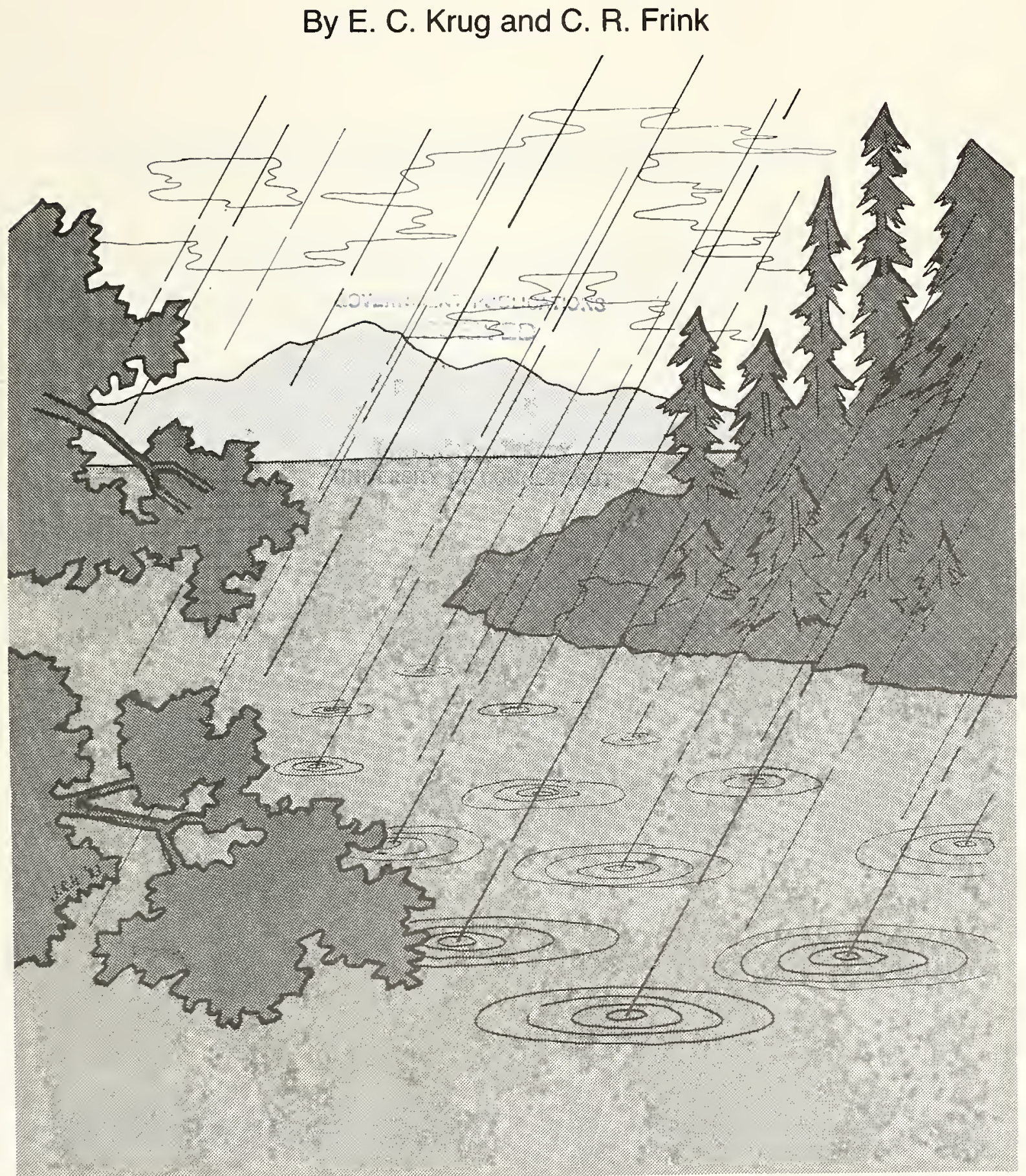

BULLETIN 811 - THE CONNECTICUT AGRICULTURAL EXPERIMENT STATION, NEW HAVEN • NOVEMBER 1983 


\section{FOREWORD}

Acid rain is widely believed to be the most serious environmental problem of the decade, if not the century. Acid rain is thought to be acidifying soils and freshwaters, dissolving and releasing aluminum in concentrations toxic to fish and plants. Acid rain is also thought to be leaching nutrients from soils, thereby lowering their fertility. Thus, the acid rain scenario predicts a gradual but frightening acidification and sterilization of soil and water.

The detrimental effects of acid rain are believed to be especially severe in mountainous landscapes in humid temperate climates where organic-rich, thin mineral soils have developed from highly siliceous bedrock under coniferous forests and heaths. These soils are already poor in nutrients, and are thought to have relatively little capacity for neutralization of acid rain. Acidification of these landscapes in the Adirondacks, northern New England, southeastern Canada and Scandinavia is said to portend the eventual acidification of highly siliceous lowland watersheds where soils are thicker and thus have greater buffering capacity.

From its inception, however, soil formation in humid temperate climates is an acidifying process mediated by the classic factors of geology, climate, biology, topography and time. It is more than coincidence that the factors thought to make landscapes sensitive to acid rain are precisely those factors that promote development of extremely acid soils where leaching of nutrients, release of aluminum and acidification of soil and water are very strongly expressed. Therefore, the simple correlation between acid rain and acidified soil and water does not establish cause and effect.

Man can influence the process of acidification directly, e.g. by adding acid rain or applying limestone, and indirectly by manipulation of the factors of soil formation, e.g. by removal of natural vegetation. Disturbance usually slows or even reverses the process of acidification, while abandonment of land increases acidification. In this review of work here in Connecticut and elsewhere, we examine the effects of acid rain and of changing land use on acidification of soil and water through their interactions with natural processes of acidification.

The report itself is in three sections: Part I, Executive Summary; Part II, Literature Review; and Part III, Bibliography. 


\title{
Effects of Acid Rain on Soil and Water
}

\author{
By E. C. Krug and C. R. Frink
}

\section{Contents}

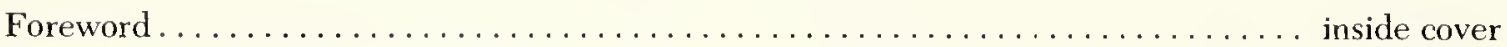

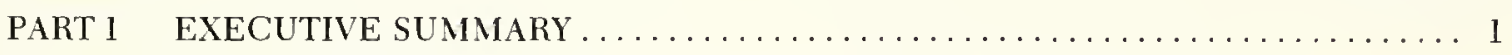

PART II $\quad$ LITERATURE REVIEW . . . . . . . . . . . . . . . . . . 3

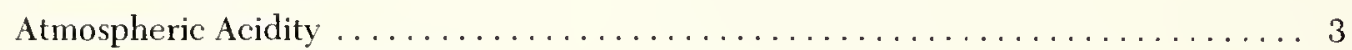

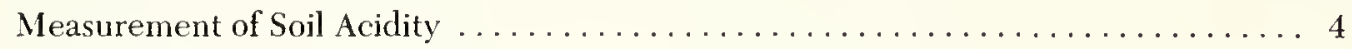

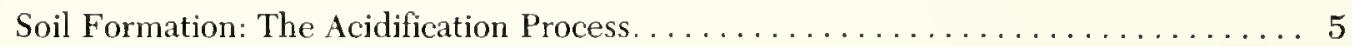

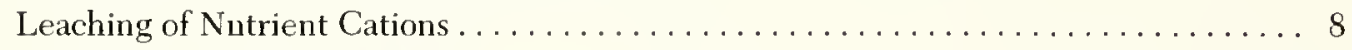

Acidification of Soil and Water ........................... 11

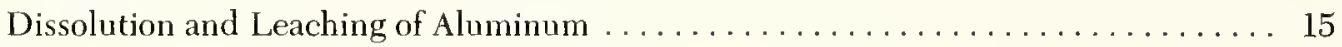

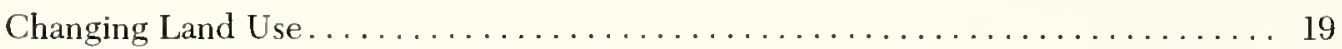

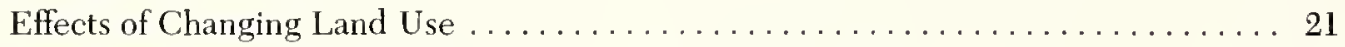

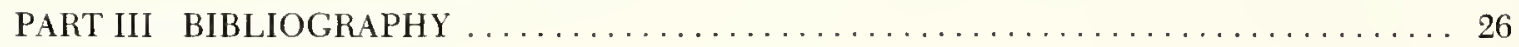




\section{Digitized by the Internet Archive in 2011 with funding from LYRASIS members and Sloan Foundation}




\section{PART I. EXECUTIVE SUMMARY}

From its very inception, soil formation in humid temperate climates is an acidifying process. Thus, the impact of acid rain on soil and water can only be judged by placing it in perspective with the natural processes of soil acidification.

While there is little doubt that rain in the industrialized areas of the world is unnaturally acid, reports of the extent of acidification are often misleading. Rain in equilibrium with the $\mathrm{CO}_{2}$ of the air has a $\mathrm{pH}$ of 5.6; hence, rain at 4.6 is said to be acidified 10-fold. In the Northeast, rain has a mean pH of about 4.3 and is said to be acidified 20-fold. These statements overlook the fact that most of the natural acidity of rain is due to $\mathrm{H}_{2} \mathrm{CO}_{3}$, a weak acid that does not completely dissociate. Measurements of $\mathrm{pH}$ only measure the free or dissociated $\mathrm{H}$-ions, which in "pure" rain at $\mathrm{pH} 5.6$ represents less than $20 \%$ of the total acidity. Thus, the strong acids in acid rain at $\mathrm{pH} 4.6$ or 4.3 represent only a two-fold or four-fold increase in total acidity.

The acidity of rain can also be expressed in terms of its ability to neutralize basic substances such as limestone. These calculations often ignore the amounts that could be dissolved by the $\mathrm{CO}_{2}$ present in unpolluted rain. Thus, 1 meter of rain at $\mathrm{pH} 4$ can dissolve about 500 $\mathrm{kg} / \mathrm{ha}$ of $\mathrm{CaCO}_{3}$, of which $50 \mathrm{~kg} / \mathrm{ha}$ represents the strong acid component of rain.

This misunderstanding of the chemistry of rainfall has created the frightening impression that man has greatly acidified rain over wide areas in recent decades. In fact, these man-made inputs are very small when compared with normal agricultural amendments with limestone, or with the tremendous amounts of acidity produced in forest soils on highly siliceous parent material.

Acidity in soils is generated by biological decomposition which creates oxides of $\mathrm{C}, \mathrm{N}$, and $\mathrm{S}$ that react with water to form acids, much as acid rain is generated by burning fossil fuels. Initially, weathering rates of freshly exposed siliceous bedrock by acid are relatively rapid. With time, rates of neutralization of acid, weathering and cation denudation decrease to very low levels. Acids accumulate in the soil and the soil is capable of acidifying water to increasingly lower $\mathrm{pH}$. Most acid produced in acid soils is not exported in runoff nor does it participate in mineral weathering. It is simply lost from the system as $\mathrm{CO}_{2}$ and $\mathrm{H}_{2} \mathrm{O}$.

Because cation exchange reactions are rapid, concern exists that extra hydrogen ions from acid rain could have the relatively immediate effect of leaching nutrient cations from the soil. Particular concern is expressed for soils under the productive forests of northern Europe and North America that are already relatively low in nutrients.

The potential for acid rain to leach nutrient cations can be estimated by comparing the ratio of these base nutrients to acid (i.e., the percent base saturation) that is found in rain to that found in soil. Data from areas of concern around the world show that the percent base saturation of rain is equal to or greater than that of the acid forest soils. Moreover, the $\mathrm{pH}$ of the soils in these areas is usually less than that of the rain. Experimental data from numerous studies confirm that reactions of acid soil witl acid rain at $\mathrm{pH} 4$, or higher, and at reasonable leaching rates does not significantly alter the leaching of bases.

Despite chemical and biological evidence that acid rain will not enhance leaching of nutrient cations from the acid forest soils of the Northeast, sontheastern Canada and Scandinavia, misconceptions about the nature of soil acidity sustain the notion that acid rain is increasing acidification of soil and water.

Areas thought to be especially vulnerable are alpinelike landscapes with thin, organic-rich soils developed on mountainous slopes from granitic parent material under coniferous and heath vegetation. These soils have long been known, however, to be more acid than the deeper soils of the lower slopes and valleys. These thin soils can be viewed as being similar to the uppermost acid horizons of podzol soils. This is illustrated by the geochemical soil catena, where upland soils act as acid and leached A horizons and lowland soils are zones of accumulation resembling the less acid $B$ horizons. As would be expected, gradients in stream acidity parallel to such a catena have been observed, but the acidification has generally been attributed solely to acid rain.

Another misconception is that the rate of acid production in soil is equal to the rate of mineral weathering plus acid export. If the only sink for $\mathrm{H}^{+}$was neutralization by mineral weathering, acid rain would eventually have a very serions impact on acid soils. However, this conceptual model ignores the enormous acid sink provided by humic materials, with resultant transformation of these acids to $\mathrm{CO}_{2}$ and $\mathrm{H}_{2} \mathrm{O}$.

Despite attention given to acidification of lakes, it is important to realize that most of the waters in "sensitive" areas are not becoming acidified. Acid waters are almost exclusively small headwater streams and lakes receiving high proportions of near surface runoff. Waters of the lower slopes and lowlands are not usually acidified since they receive a large proportion of their water from near-neutral subsoils where contact time is sufficient for 
neutralization of acid by mineral weathering. Similarly, we do not expect that natural soil acidification or acid rain will acidify drainage to lakes and streams in deep granitic soils in lowlands in Connecticut.

Acid rain falling directly on lake surfaces can contribute to their acidification. In watersheds with granitic soils, the alkalinity of the drainage water will be low. In such lakes with exceptionally small ratios of drainage area to lake area, inputs of acid rain may exceed inputs of alkalinity. One such case has been documented in Canada and others may well be found. Lakes with small ratios of drainage area to lake area may have alkalinities reduced somewhat by direct inputs of acid rain.

Acid rain is also said to be dissolving and leaching toxic quantities of aluminum into lakes and streams. However, large amounts of soluble ionic aluminum are normally present in acid soil. Indeed, below $\mathrm{pH} 5$, the cation exchange sites of acid siliceous soil materials are nearly completely saturated with ionic aluminum. The solubilization of aluminum by acid rain is not likely because soil $\mathrm{pH}$ is not altered by acid rain. The theory that increased $\mathrm{SO}_{4}$ from acid rain enhances leaching ignores the direct evidence that acid rain is not measurably enhancing rates of leaching from soils or watersheds.

Societal and technological changes associated with the demographic transition are underlying factors responsible for both regional acid rain and drastic changes in land use. The entire forest of northern Europe still bears the influence of man. Careless land-use practices were transported from Europe to eastern North America, where forests of the lowlands and foothills were cleared for farming or cut for lumber and fuel. Later, the sprucefir forests on the steep mountainous slopes were clearcut for pulp. Fortunately, the landscape was sufficiently resilient that the forests of northern Europe and eastern North America are increasing dramatically in both area and biomass.

The net result has been a slow and steady increase in depth and acidity of the forest floor as reforestation progresses. Indeed, the landscapes thought to be impacted by acid rain are precisely those that develop the greatest soil acidifiation following disturbance. There is little doubt that changes in land use of the magnitude reported here can contribute significantly to acidification of lakes and streams.

In conclusion, direct acidification of lakes by acid rain has been documented where watersheds are small relative to the lake. We believe that the largest canse of acidification of lakes and streams is generally the revegetation and reforestation of disturbed land. The degree to which acid rain may be accelerating this natural process of acidification needs to be evaluated on a watershed basis. These natural sources of soil acidity and their interactions with acid rain need to be evaluated in estimating the benefits expected from proposed reductions of emissions of oxides of nitrogen and sulfur. 


\section{PART II. LITERATURE REVIEW}

\section{Atmospheric Acidity}

Biological materials contain carbon, nitrogen and sulfur that when burned create gaseous oxides that react with water in the atmosphere to form the corresponding acids: $\mathrm{H}_{2} \mathrm{CO}_{3}, \mathrm{HNO}_{3}$, and $\mathrm{H}_{2} \mathrm{SO}_{4}$. High temperature combustion also combines atmospheric nitrogen and oxygen to form acidifying oxides of nitrogen. Acid rain has been recognized since the early 1700 's as a local environmental problem caused by the burning of fossil fuels (Cowling, 1980 and 1982). In Connecticut, rainfall data collected from 1929-1948 indicate that the rain has probably been strongly acidified near Hartford since 1929 (Frink and Voigt, 1976).

When coal and wood were major fuels much of this acidity was apparently neutralized by particulate matter. Likens and Bormann (1974) note that considerable sulfur was present in rain in upstate New York prior to 1950 , but the rain was not unnaturally acid because of neutralization by smoke. Gorham and Overrein have made similar observations in Europe (Likens and Bormann, 1974). The post World War II economic boom resulted in greatly increased demands for energy which then increased local air pollution problems. The use of tall smokestacks, particle precipitators and cleaner burning fuels soon converted these local soot problems into regional acid rain (Likens and Bormann, 1974; and Patrick et al., 1981). Since the mid-1950's, acid rain has spread over wide areas of North America and northern Europe. The strongly acidified central areas of these air masses have likewise spread (Likens et al., 1979). Some atmospheric chemists believe that further increases in emissions of acid will not lower the $\mathrm{pH}$ of rain below about 4 , but rather will increase the arcas receiving acid rain (Hileman, 1982). Support for this view is available from data at the Hubbard Brook Experimental Watershed in New Hampshire where the pH of rain has been about 4.1 since 1964 (Likens et al., 1977, pp. 35-41). Similarly, little change in acidity of rain has been observed at nine USGS monitoring stations in New York during the period 1965-1978 (Peters et al., 1982).

Because pure water at equilibrium with the carbon dioxide in the atmosphere has a $\mathrm{pH}$ of 5.6-5.7, precipitation with a pH less than 5.6 is defined as acid rain (EPA, $1980 \mathrm{a}$ and b). However, unpolluted rain can be more or less acid than $\mathrm{pH}$ 5.6. Biogeochemical cycling of nutrients causes emissions of oxides of nitrogen and sulfur to the atmosphere, and lightning produces oxides of nitrogen that are converted to nitric acid. Thus, it is not sur- prising that the mean $\mathrm{pH}$ of rainfall is less than 5.6 at locations well removed from industrial areas (Charlson and Rodhe, 1982). The rainfall at islands in the Indian and Pacific Oceans, and locations in the Amazon Basin has been reported to have mean $\mathrm{pHs}$ in the range of 4-5 (Hansen, 1981; and Kerr, 1981). Recent research in Norway has assumed that unpolluted rain has a $\mathrm{pH}$ of 5.05 (Seip et al., 1979b; and Christophersen et al., 1982). Rain in the airsheds of other regions has a $\mathrm{pH}$ above 5.6 because of dust as observed in the Great Plains of the United States and Canada, and in parts of the far north (Winkler, 1976; and Hileman, 1981). Also, soil development in these regions is not strongly acidifying.

Globally, man-made sources of oxides of nitrogen and sulfur are believed to be less than natural emissions. However, there is little doubt that man has strongly acidified rain in airsheds with high concentrations of people and industry. Reports of the extent of acidification are often misleading. Because the $\mathrm{pH}$ scale is logarithmic, rain at $\mathrm{pH} 4.6$ is said to have been acidified 10-fold relative to rain at $\mathrm{pH} 5.6$. In heavily polluted airsheds such as the northeastern United States and southernmost Norway, rain has a mean $\mathrm{pH}$ of about 4.3 (Glover et al., 1980; and Kerr, 1981), and is said to be acidified 20-fold. However, most of the acidity of rain at pH 5.6 is due to $\mathrm{H}_{2} \mathrm{CO}_{3}$, a weak acid that does not completely dissociate into $\mathrm{H}^{+}, \mathrm{HCO}_{3}{ }^{-}$and $\mathrm{CO}_{3}{ }^{=}$ions. Measurenents of $\mathrm{pH}$ determine only the free $\mathrm{H}^{+}$, which in "unpolluted" rain at $\mathrm{pH} 5.6$ represent less than $20 \%$ of the total acidity. Thus, the amounts of sulfuric or nitric acid present in acid rain at $\mathrm{pH} 4.6$ or 4.3 represent a two-fold or four-fold increase in total acidity respectively; not the 10- and 20-fold increases often reported.

The acidity of rain can also be expressed in terms of its capacity to dissolve and neutralize basic materials such as limestone $\left(\mathrm{CaCO}_{3}\right)$. This is useful because it expresses the potential impact of acid rain on earth and building materials relative to what would be dissolved by $\mathrm{CO}_{2}$ normally present in the rain. Dissolution of basic substances, including those in silicate rock, is expressed in terms of the carbonate equilibria because of the presence of $\mathrm{H}_{2} \mathrm{CO}_{3}$, e.g.

$$
\begin{gathered}
\mathrm{CaAl}_{2} \mathrm{Si}_{2} \mathrm{O}_{8}+2 \mathrm{H}_{2} \mathrm{CO}_{3}+\mathrm{H}_{2} \mathrm{O} \rightleftharpoons \mathrm{Ca}^{+2}+ \\
2 \mathrm{HCO}_{3}^{-}+\mathrm{Al}_{2} \mathrm{Si}_{2} \mathrm{O}_{5}(\mathrm{OH})_{4}
\end{gathered}
$$

(Stumm and Morgan, 1970, pp. 390-393). Likens et al. 
(1977, p. 43) state that $1 \mathrm{~m}$ of rain at $\mathrm{pH} 4$ can dissolve 50 $\mathrm{kg} / \mathrm{ha}$ of $\mathrm{CaCO}_{3}$. This ignores the acidity of $\mathrm{H}_{2} \mathrm{CO}_{3}: 1 \mathrm{~m}$ of unpolluted rain can actually dissolve about $400 \mathrm{~kg} / \mathrm{ha}$ of $\mathrm{CaCO}_{3}$ (Garrels and Christ, 1965, pp. 74-92) to 500 $\mathrm{kg} / \mathrm{ha}$ (Stumm and Morgan, 1970, pp. 161-237) depending on the precise values of the thermodynamic constants chosen. Correctly put, $1 \mathrm{~m}$ of rain at $\mathrm{pH} 4$ can dissolve 450 to $550 \mathrm{~kg} / \mathrm{ha}$ of $\mathrm{CaCO}_{3}$, of which $50 \mathrm{~kg} / \mathrm{ha}$ represents the strong acids in acid rain. Because $\mathrm{CaCO}_{3}$ and $\mathrm{H}_{2} \mathrm{SO}_{4}$ have similar equivalent weights, only about $50 \mathrm{~kg} / \mathrm{ha}$ of $\mathrm{H}_{2} \mathrm{SO}_{4}$ is required to acidify one meter of acid rain to $\mathrm{pH} 4$. Very little strong acid is required to acidify large volumes of water.

Acidity is also deposited as acidic particulates and sorbed gaseous oxides and may constitute up to $50 \%$ of the total amount of acid deposited (EPA, 1980a). At Hubbard Brook, this dry deposition is estimated to contribute one-third of the input of sulfur (Eaton et al., 1978). Dry deposition in the Adirondacks is estimated to range from 9 to $13 \%$ of the total (Johannes and Altwicker, 19S0) while in southernmost Norway, dry deposition is estimated to account for $40 \%$ of the total (Gjessing et al., 1976). The relative amounts of wet and dry deposition are largely controlled by distance from the source; distant areas receive relatively more in wet forms while nearby areas receive more acidic particulates and gaseous oxides. Ulrich (1978) calculates that forests near industrial areas scrub the atmosphere of such dry acids: $42 \%$ of the total deposition of acid under beech forests is dry, and $74 \%$ is dry under spruce forests.

Not all atmospheric acidity reaches the ground. In the Solling District of Germany, 58\% of atmospheric acidity is nentralized before it reaches the ground (Ulrich, 1978). In the northeastern United States, Pearson and Fisher (1971) calculate that two-thirds of the $\mathrm{H}_{2} \mathrm{SO}_{4}$ in rain is neutralized by calcium in atmospheric dust. There are materials other than dust that also neutralize these acids. At Hubbard Brook, the mean $\mathrm{pH}$ of rain was 4.06 during the summer of 1969. After passing through the canopy of a northern hardwood forest, the rain had a mean pH of 5.01 (Hornbeck et al., 1976). Cole and Johnson (1977) observed that most free $\mathrm{H}^{+}$was neutralized when acid rain passed through the canopy of a Douglas fir forest in Washington. Cronan and Schofield (1979), however, did not observe net neutralization of acid by the canopy of a balsam fir forest in New Hampshire. It is not clear as to what extent acid is reacting with foliar materials or with detrital materials deposited on plant surfaces (Sinith, 1981, p. 187).

As snow or ice ages, it beomes less acid. The snowpack at Hubbard Brook loses half or more of its free acid- ity over the winter (Hornbeck et al., 1976; and Likens et al., 1977, pp. 41-46). Two American atmospheric monitoring networks report a puzzling loss of acidity in samples of rain and snow between collection in the field and analysis in the laboratory (Pack, 1980). One explanation is that snowpack acidity is lost by reaction with plant litter in the snow. Other explanations involve phase separation, where concentrated liquid salt solutions work their way out of the still frozen, purer water. Such acidity is lost and, therefore, not measured (Clement, 1966; Johannessen and Henriksen, 1977; Wright and Dovland, 1977; and Seip, 1980b). However, this does not explain losses of acidity from samples stored in containers.

Neutralization of acidity in ice and snow, as well as in water, shonld not be unexpected. Rain and snow are not pure; water condenses on fine particles, and $\mathrm{H}^{+}$is very reactive in both ice and water. The mobilities of $\mathrm{H}^{+}$and $\mathrm{OH}^{-}$in water and in ice are much greater than those of other ions. This is because "liquid" water is actually a mixture of ice clusters and gaseous water molecules. Other ions and particles slowly bounce their way through water, but not $\mathrm{H}^{+}$or $\mathrm{OH}^{-}$. While physical chemists debate the exact mechanism by which these ions move so swiftly, all explanations involve the icewater clusters found in "liquid" water. These clusters offer frequent obstacles to the quick transport of $\mathrm{H}^{+}$and $\mathrm{OH}^{-}$because the ice structure is not continuous in "liquid" water. Solid ice has a continuous structure; therefore, the movement and reaction of $\mathrm{H}^{+}$and $\mathrm{OH}^{-}$is at an optimum while other particles are usually frozen in (Samoilov, 1965; Zundel, 1969; and Adamson, 1973, pp. 321-322, 506-509). Indeed, reaction kinetics indicate that the mobility of the bydrogen ion in ice crystals is one or two orders of magnitude higher than in the liquid phase (Zundel, 1969, p. 229).

Thus, although investigators found that ice originating as snow some $\mathbf{1 8 0}$ years ago in Greenland had a $\mathrm{pH}$ of 6 to 7.6 (Likens et al., 1979; and EPA, 1980b), this does not prove that the original snow was of that $\mathrm{pH}$.

In conclusion, misunderstanding or misrepresentation of the chemistry of rain has created the frightening impression that man has greatly acidified rain over wide areas in recent decades. That these man-made sources are actually rather small is illustrated by the fact that much acidity is neutralized by atmospheric dust and by brief contact with biological materials and the detritus accumulated on surfaces. Moreover, acid rain is not the only source of acidity that can impact soil and water. Considerable acidity is generated and retained in soils under natural conditions, particularly in forest soils on highly siliceous geologic parent material in humid temperate climates.

\section{Measurement of Soil Acidity}

Measurements of acid in soil are similar to those discussed for rain. The soil analog to the total acidity of rain is exchange acidity, i.e. those hydrogen ions that are rapidly exchangeable with solutions of neutral salts.
Typical acid humus has an exchange acidity of at least $1 \mathrm{eq} / \mathrm{kg}$. The strong acid in an equal weight of soil solution or acid rain at $\mathrm{pH} 4$ is $1 \times 10^{-4} \mathrm{eq} / \mathrm{kg}$. Thus, exchange acidity is generally many thousands of times 
greater than the acidity expressed as the $\mathrm{pH}$ of soil solutions or acid rain. For soil minerals, the proportion of exchange acidity relative to free hydrogen ions is less than that of acid humus by about an order of magnitude (Figure 1). However, the bulk density of mineral soils is greater than that of humus. Therefore, the exchange acidity of acid mineral soil is only several-fold less than that of an equal volume (or depth) of acid humus (Lunt, 1932; and Hoyle, 1973).

As with acid rain, the acidity of soil is also expressed as $\mathrm{pH}$. Typically, the $\mathrm{pH}$ of an aqueous solution mixed with the soil is measured. Because soils are weak acids with both minerals and organic macromolecules acting as immobile anion plases, thermodynamic interpretation of soil pH is uncertain. Nevertheless, certain principles apply. The larger the ratio of water to soil, the higher will be the measured pH. Similarly, increasing salt concentrations will lower the measured $\mathrm{pH}$. Because salt concentrations in soil vary seasonally, the $\mathrm{pH}$ measured in water, $\mathrm{pH}\left(\mathrm{H}_{2} \mathrm{O}\right)$, may also vary. As a practical matter, soil $\mathrm{pH}$ is often measured in $0.01 \mathrm{M} \mathrm{CaCl}_{2}, \mathrm{pH}\left(\mathrm{CaCl}_{2}\right)$, which minimizes salt effects and approximates the ionic strength of most nonsaline soils. The difference between $\mathrm{pH}\left(\mathrm{H}_{2} \mathrm{O}\right)$ and $\mathrm{pH}\left(\mathrm{CaCl}_{2}\right)$ for mineral soil can be $0.5 \mathrm{pH}$ unit, and for acid humus can be up to $1 \mathrm{pH}$ unit.

Soil acidity can also be expressed as the amount of $\mathrm{CaCO}_{3}$ that can be neutralized. Extraction with a mixture of barium chloride and triethanol amine is often used in place of equilibration with limestone because of its ease and speed. Acidity determined in this fashion for

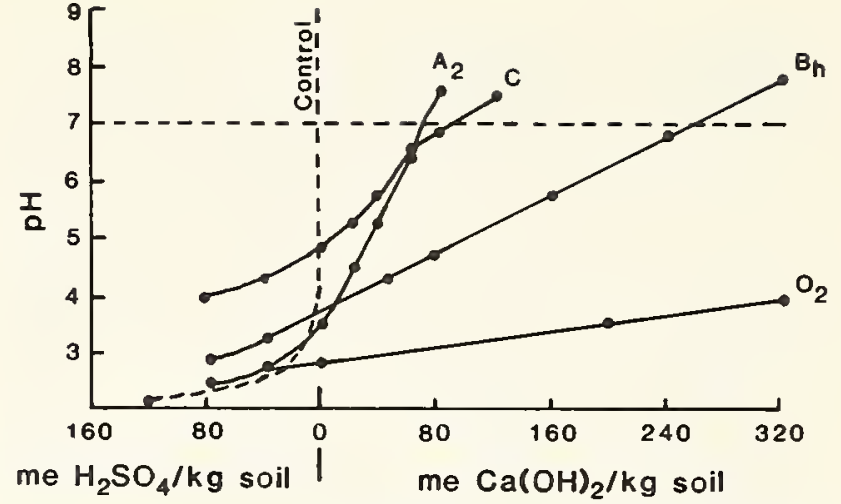

Figure 1. Changes in pH Upon Additions of Acid and Base to Swedish Podzol Soil Materials."
* $5 \mathrm{~g}$ electrodialyzed soil mixed with $60 \mathrm{ml} 0.01 \mathrm{~N} \mathrm{CaSO}_{4}$.
$\mathrm{O}_{2}=$ mor humus
$A_{2}=$ bleached highly weathered mineral soil
$B_{n}=$ humus-enriched subsoil
$\mathrm{C}=$ sandy-stony glacial parent material
Control $=$ solution only.
Modified from Figure 2b, Mattson and Gustafsson, 1934.

acid humus may be several times its exchange acidity and probably represents strongly bound or occluded $\mathrm{H}^{+}$and $\mathrm{Al}^{+3}$. For mineral soils, this acidity usually only adds fractionally to exchange acidity and mostly represents bound or occluded $\mathrm{Al}$ that hydrolyzes slowly.

\section{Soil Formation: The Acidification Process}

Hans Jenny (1941) in his classic text expressed the five soil-forming factors of geology, climate, biology, topography and time in a first order partial differential equation. His goal was to establish quantitative estimates of each factor while holding all others constant. While this has not been accomplished to the degree that Jenny must have hoped, it still provides a framework for the discussion of soil formation.

Although influenced by geology, the more mature a soil becomes the more it differs from its geologic parent material. In humid temperate climates of the world, soil formation is an acidifying process. Thus, soils in such areas would be expected to be more acid than their parent materials. For example, although water percolating through freshly-ground granite will be alkaline $(\mathrm{pH} 8$ to 9), as will water percolating through limestone, soils developed on granite will be quite acid. The strength of the acidification process is such that even mature soil developed on limestone or marble can be surprisingly acid (Lunt, 1948; Krebs and Tedrow, 1957; and Provan et al., 1969).

There are far more basic than acidic substances in most rock types, even in so-called acid rocks such as granite. While chemical oxidation of reduced elements in parent materials increases acidity, it cannot account for the extremely acid podzolized soil and related acid peaty soils formed on granite-like rocks in humid temperate climates. Acidification of these soils is biological: hence, the soils are most acid at the surface where most decomposition occurs (Table 1).

Acidity is generated by decomposition which creates oxides of $\mathrm{C}, \mathrm{N}$ and $\mathrm{S}$ that react with water to form acids, much as acid rain is generated by burning fossil fuels. Initially, weathering rates of freshly-exposed siliceous bedrock by acid are relatively rapid. The exchange sites are largely base saturated (Figure 3) and cation leaching is principally of bases (Figure 2, pathway $3 \mathrm{~d}$ ). Because the partial pressure of $\mathrm{CO}_{2}$ in soil can be as much as 100 times that in the atmosphere, potential weathering rates by $\mathrm{H}_{2} \mathrm{CO}_{3}$ are immense. In carbonate-bearing sand dunes that are newly formed, potential rates of weathering by carbonic acid are nearly realized (Table 2). Neutralization of hydrogen ions by mineral weathering favors the continued dissociation of carbonic acid to $\mathrm{H}^{+}$ and $\mathrm{HCO}^{-3}$ (Figure 2, pathway 2c). Thus basic cations in runoff resulting from weathering of minerals by $\mathrm{H}_{2} \mathrm{CO}_{3}$ are accompanied by bicarbonate anions (Figure 2 , pathway $3 \mathrm{~d}$ ).

With time, both the ecology and chemistry of the soil change. Rates of neutralization of acid, weathering and cation denudation decrease to very low levels. Acids accumulate in soils and $\mathrm{pH}$ decreases accordingly. Most 
$\mathrm{H}_{2} \mathrm{CO}_{3}$ is lost as $\mathrm{CO}_{2}$ and $\mathrm{H}_{2} \mathrm{O}$ (Figure 2, pathway 2c) with little consumed by mineral weathering, which is reflected by the low bicarbonate alkalinity of water in watersheds with acid soils. Most exchange sites are dominated by $\mathrm{H}^{+}$and ionic aluminum (Figure 3) and the remaining basic nutrient cations are tightly held: the ease of their replacement by acid decreases with decreasing base saturation. Biologically, the ecosystem that evolves is one that cycles nutrients tightly and tolerates quantities of ionic aluminum that are toxic to many organisms (Lunt, 1938 and 1948).

The most obvious physical change accompanying acid soil development is the accumulation of a surface humus layer frequently underlain by bleached mineral soil (Figure 4). Earthworms and other organisms that mix litter with mineral soil cannot survive in this acid environment.

Microbial populations also change. Production of simple organic acids is slight (Mattson and KoutlerAndersson, 1946; and Schnitzer and Desjardins, 1969) and production of partially-oxidized humic acids (with molecular weights up to $500,000 \mathrm{amu}$ ) is apparently favored. Humic acids have the peculiar distinction of more strongly acidifying their environment than do the final oxidation products of $\mathrm{CO}_{2}$ and $\mathrm{H}_{2} \mathrm{O}$. Weathering of the upper mineral horizons (Table 1 ) is now controlled by export of $\mathrm{H}^{+}$and organic acids from the overlying humus.

The formation of this acid humus layer creates a chemical environment even more favorable for its formation

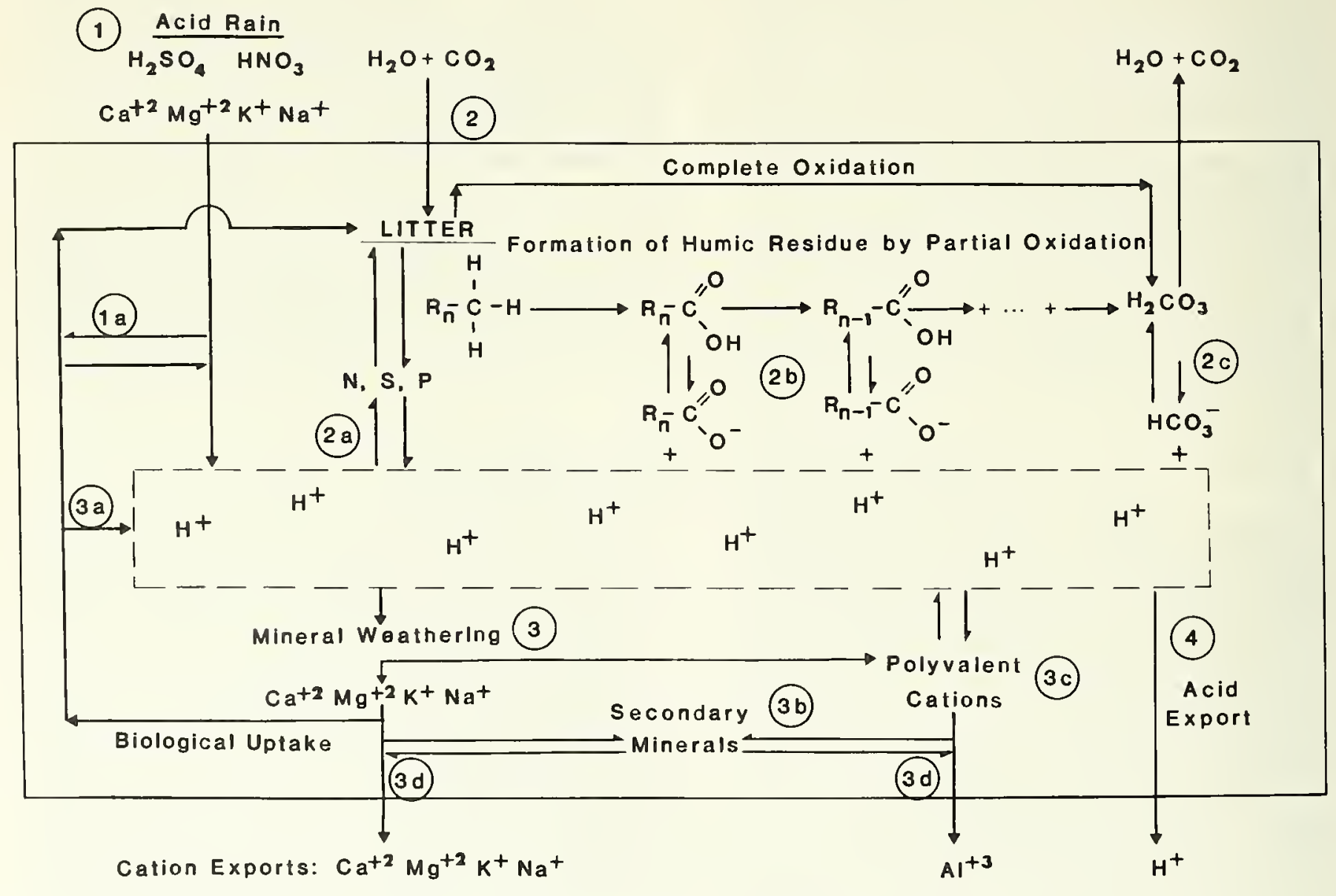

Anion Exports: $\mathrm{SO}_{4}^{-2} \mathrm{NO}_{3}^{-} \mathrm{HCO}_{3}^{-} \mathrm{RCOO}^{-} \mathrm{Cl}^{-}$

Figure 2. Major Sources and Sinks of Acidity in Soil.

Acid rain (1) is a source of acidity, and its composition may be altered before reaching the soil (1a). Although biological processes (2) are net sources of acidity, this obscures the fact that they serve as a substantial sink in acid soils through production of weak organic acids (2b) with ultimate conversion to $\mathrm{CO}_{2}$ and $\mathrm{H}_{2} \mathrm{O}$ (2). Mineral acids (2a) can be cycled rather tightly with some $\mathrm{S}$ and $\mathrm{N}$ lost to the atmosphere by microbial activity and some $\mathrm{S}$ and $\mathrm{P}$ can be converted to essentially insoluble secondary minerals. Weathering of minerals (3) generally consumes acid in excess of cation export (30), as secondary minerals (3b) and hydrolysis products of aluminum, iron, manganese (3c) accumulate in soil. Aggrading vegetation causes net cation uptake (3a), and contributes to acidification. Rain less acid than the soil solution promotes acidification by hydrolysis (30. The electrical charges exported by cations (3d) and acids (4) are balanced principally by anions shown at the bottom of the figure. 
Table 1. Northeast Podzol Soil Profile Data.

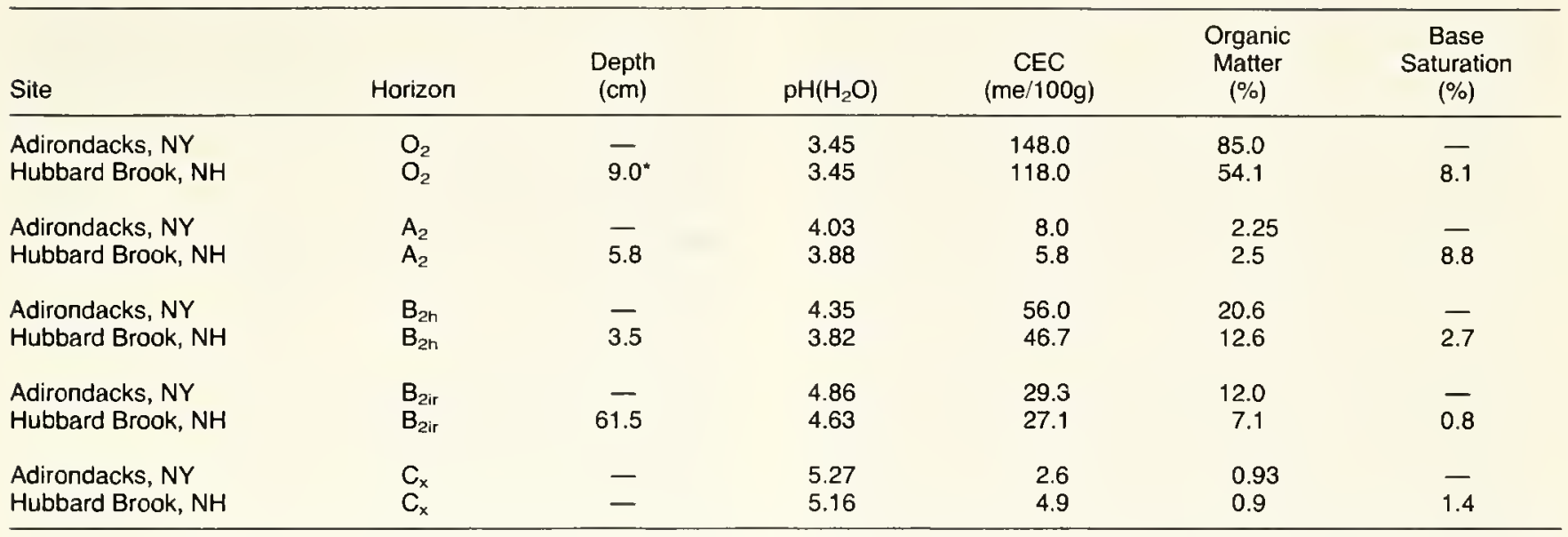

Both soils are Beckett pedons, well developed podzol soils. Adirondack soil data is pre-acid rain data from Lutz and Chandler (1946, p. 398). Hubbard Brook soil data is from Wood (1980, pp. 16 and 92) and Whittaker et al. (1979). Hubbard Brook \% organic matter is \% weight loss on ignition and $\mathrm{B}_{2 \mathrm{ir}} \mathrm{CEC}$ (cation exchange capacity) is grand average of $3 \mathrm{~B}_{2 \mathrm{ir}}$ subhorizons. Hubbard Brook $\mathrm{O}_{1} \%$ base saturation $=14.5 \%$.

Percent base saturation $=\frac{\Sigma\left(\mathrm{Ca}^{+2}+\mathrm{Mg}^{+2}+\mathrm{K}^{+}+\mathrm{Na}^{+}\right)}{\mathrm{CEC}}$

* Depth of $\mathrm{O}_{1}+\mathrm{O}_{2}$ horizons

since the increased acidity decreases the solubility of humic acids. This is because most soil humic materials are in a solid or gel state. Electrostatic repulsion between like charges of dissociated groups is required for dissociation of any humic fraction. Therefore, polar functional groups and charged sites with counter-ions will be strongly solvated in water. Replacement of readily dissociated counter-ions by $\mathrm{H}^{+}$causes contraction and precipitation of humic substances by reduction of charge repulsion between weakly dissociated carboxyl groups, enhanced hydrogen bonding, and expulsion of water from within the macromolecular humate structure (Hayes and Swift, 1978, p. 281: Ghosh and Schnitzer, 1980; and Ritchie and Posner, 1982).

A common misconception is that acid humus accumulates because of greatly decreased rates of decomposition of organic matter. Although this is true where peats develop under sparse vegetation, it is not true for the productive forests on acid humus soils in the Northeast, Canada and Scandinavia where concern about the effects of acid rain is greatest. The misconception probably arises because the acid mor humus of these soils accumulates on top of the mineral soil, rather than being mixed with the mineral soil as in a more alkaline mull humus. This was first made clear by Müller in the 1880 's and verified and elaborated upon 50 years ago by Romell (1932). He showed that soil organic matter content, litter production, evolution of $\mathrm{CO}_{2}$, and the rate of organic matter turnover were similar for northern European and North American forests for comparable sites regardless of soil type. Even the exceedingly thick and acid soils (folists) under coniferous slope forests in the Adirondacks have reasonable rates of turnover. Thus, the difference between formation of mor humus versus mull humus is type of decomposition rather than rate.
Romell's (1932) observation of rates of production and decomposition of forests on acid humus can be illustrated with data from Hubbard Brook. The soil is extremely acid and low in nutrients (Table 1) yet the forest is very productive: during 1956-1960 net productivity was $11,000 \mathrm{lbs} /$ acre per annum, of which about 6,000 lbs. was litter (Whittaker et al., 1974). The rate of humus turnover was estimated to be 60 years (Johnson et al., 1968), which is about the same rate observed in less acid and more fertile soils. The rate of turnover of the considerably thicker forest floor under high altitude balsam fir at nearby Mount Moosilauke is estimated to be only 30 years (Cronan, 1978, p. 68).

Podzols form relatively rapidly on coarse-grained and

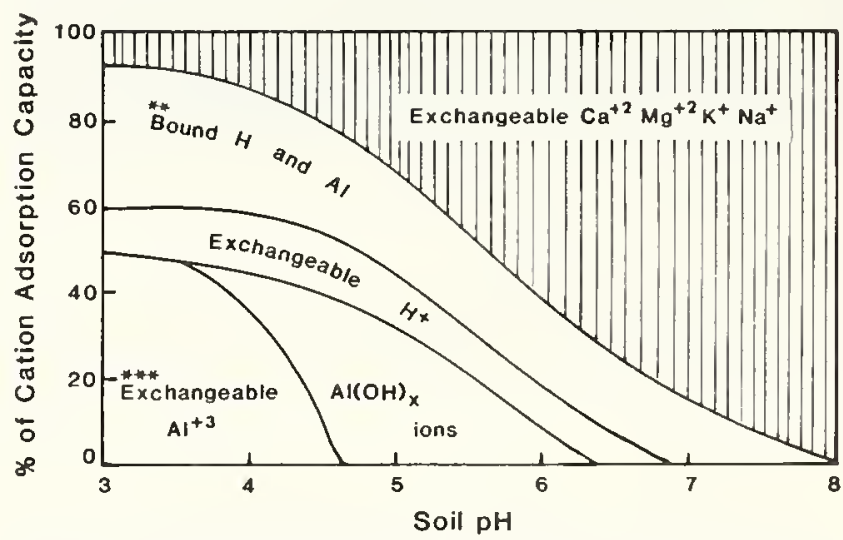

Figure 3. Generalized Relationship Between Soil pH and Adsorbed Cations in Mineral Soil.*

* From Brady, 1974, p. 376.

** The difference between $\mathrm{BaCl}_{2}$-TEA and exchange acidity.

*** And probably some $\mathrm{Fe}(\mathrm{OH})_{x}$ ions in the more acid range. 
The potential for nutrient leaching can be estimated by comparing the ratio of base nutrients to acid in rain to that in soil. This concept is widely used in arid regions where the ratio of sodium to calcium in irrigation water is compared with the same ratio in soil to determine whether irrigation will make the soil more saline. The presumed effects of acid rain on the base nutrient status of soil are greatly exaggerated if the base cations in the rain are ignored (Wiklander, 1973/74, 1975, and 1980; and Frink and Voigt, 1976; McFee et al., 1976; and Bache, 1950).

Around the world, percent base saturation of rain (excluding sodium) is equal to or greater than that of the acid forest soils. Also, the $\mathrm{pH}$ of the soils in these areas is usually less than that of the rain (Låg, 1968; Pearson and Fisher, 1971; Wiklander, 1973/74; Gjessing et al., 1976; Odén, 1976; Clayton et al., 1977; Likens et al. 1977, p. 32; Pilgrim and Harter, 1977; Johannes and Altwicker, 1980; Molliter and Berg, 1980; Overrein et al., 1980, p. 32; Vitousek et al., 1982; and Table 1). It is difficult to see how such soils will be depleted of basic nutrient cations by rain of equal or greater base saturation.

The presumed impact of acid rain is further reduced in acid soils (less than $\mathrm{pH} 5$ ) with low base saturation because base cations are strongly held on cation exchange sites (Wiklander, 1946, 1973/74, 1975, and 1980; McFee et al., 1976; Tamm, 1976a and b; Bache, 1980; and Voigt, 1980). Addition of hydrogen ions $(\Delta \mathrm{H})$ to such soils at rates typical of acid rain causes a relatively small desorption and leaching of base cations $(\Delta \mathbf{M})$ so that $\Delta \mathrm{M} / \Delta \mathrm{H} \ll 1$. Thus, the chemistry of acid soils greatly minimizes the leaching of nutrient cations.

Studies of the reactions of acid soil with acid rain at $\mathrm{pH} 4$ or higher confirm that leaching of bases is little altered. Experiments lasting up to five years show no change in percent base saturation of acid soil (Overrein, 1972; Wiklander, 1973/74, and 1975; Abrahamsen et al., 1976; Abrahamsen, 1980; Abrahamsen and Stuanes, 1980; Overrein et al., 1980; Singh et al., 1980; Stuanes, 1980; Morrison, 1981; and Smith, 1981, pp. 187-188). Forcing large volumes of water through walled lysimeters has long been known to enhance leaching (Kohnke et al., 1940), but such treatments are too extreme to predict the long-term effects of acid rain.

If the acidity of rain should increase dramatically, say from about $\mathrm{pH} 4.0(\sim 1 \mathrm{Keq} / \mathrm{ha}$ per annum) to $\mathrm{pH} 3$ or 2 $(\sim 10-100 \mathrm{Keq} / \mathrm{ha}$ per annum), the base saturation of the rain would decrease by 10 - to 100 -fold. The base saturation of acid rain would then be less than that of acid soils, which commonly ranges from 1 to $20 \%$, with the higher figures generally occurring in the surface organic horizons. Also, the greater the amount of acid addition $(\Delta \mathrm{H})$, the greater the efficiency in replacing base cations $(\Delta \mathrm{M})$, i.e., $\Delta M / \Delta H$ increases (Wiklander, 1946, 1973/74, and 1975). Therefore, more bases will be removed from acid soil not only by increases in acid but also by proportionally greater removal of bases per unit addition of acid. Some relatively long-term studies in Canada and Norway indicate the effects of extreme acidification of rain. Studies with two soils in Canada during 3 years
(Morrison, 1981) showed no effects of leaching by rain down to $\mathrm{pH} 3$. Treatment with rain at $\mathrm{pH} 2$ greatly increased leaching, but the effects on base saturation of the soils were not reported. Three Norwegian soils were studied over a period of 4 to 5 years (Stuanes, 1980). Tieatment with rain at $\mathrm{pH} 3$ increased leaching about $10 \%$ and decreased base saturation of humus by $3-4 \%$. Treatment with rain at $\mathrm{pH} 2$ greatly enhanced leaching and also greatly decreased the base saturation of the surface horizons, but did not affect the B horizon.

Thus, it appears that rain with $\mathrm{pH} 3$ or less can decrease the base saturation of acid soils. As we noted earlier, it is unlikely that the $\mathrm{pH}$ of rain will decrease to such low values. Locations close to sources of emissions can receive considerable acidity in dry deposition. In the Northeast, however, rainfall near emission sources is relatively high in base saturation (Pearson and Fisher, 1971). The relative effects of these two offsetting factors near sources of emissions remains to be determined.

Studies of acid soil ecosystems around the world show that they cycle nutrients tightly and lose nutrients slowly, even in areas receiving high rates of acid rain (Johnson et al., 1969; Likens et al., 1977; Johnson, 1979; and Andersson et al., 1980). The biological control of nutrient leaching is well illustrated by forest soil lysimeters in Connecticut (Table 3). In the presence of roots, as noted by Frink and Voigt (1976), nutrient losses from undisturbed lysimeters were even less than inputs from rain. In the absence of roots, leaching was increased by an order of magnitude. Not all of the differences in leaching can be attributed to the absence of roots, since the soil was disturbed by their removal. Disturbance exposes fresh surfaces that weather rapidly, and, in the

Table 3. Leaching Losses of Several Nutrient Elements from Connecticut Forest Soils.

\begin{tabular}{llrc}
\hline \multirow{2}{*}{ Element } & & \multicolumn{2}{c}{ Annual loss (kg/ha) } \\
\cline { 3 - 4 } $\mathrm{N}$ & Lysimeter type* & Red Pine & Mixed Hardwoods \\
& Tank & 48.9 & 93.2 \\
$\mathrm{~S}$ & Pan & 1.2 & 1.6 \\
& Tank & 37.0 & 42.2 \\
$\mathrm{~K}$ & Pan & 2.2 & 6.2 \\
& Tank & 26.4 & 49.3 \\
$\mathrm{Ca}$ & Pan & 1.1 & 4.1 \\
& Tank & 53.9 & 27.7 \\
$\mathrm{Mg}$ & Pan & 3.4 & 2.5 \\
& Tank & - & 7.9 \\
$\mathrm{P}$ & Pan & - & 1.6 \\
& Tank & - & 0.27 \\
& Pan & - & 0.08 \\
\hline
\end{tabular}

From Lunt (1948).

" Installed under forest plus $10 \mathrm{~cm}$. mineral soil. Tank lysimeters are under disturbed soil with no roots. Pan lysimeters are under undisturbed soil with active roots. Red pine data for 1934-1936 near Hartford. Hardwood data for 1938-1940 near New Haven. 
absence of vegetation, nutrients are readily leached (Joffe, 1933; Kohnke et al., 1940; Mattson and KoutlerAndersson, 1942; and Lunt, 1948). The importance of vegetation in conserving nutrients is further illustrated by data from Hubbard Brook where a watershed was clearcut and regrowth was inhibited with an herbicide. For two years following the cutting, the concentrations of $\mathrm{Ca}^{+2}, \mathrm{Mg}^{+2}$ and $\mathrm{K}^{+}$in streamwater increased $417 \%, 408 \%$ and $1558 \%$ respectively (Likens et al., 1970).

When nutrients are scarce relative to demand, forest ecosystems in acid soils are even more efficient in conserving nutrients. For example, watersheds whose forests are gaining biomass (i.e., aggrading) after lumbering export considerably less nutrients than mature forests where nutrient uptake is balanced by nutrient release from decomposition (Vitousek, 1977; and Likens et al., 1978). This uptake of nutrients by the rapidly growing forest is supplied by precipitation and by mineral weathering. With former lumbering practices, these losses were 0.1 to $0.6 \mathrm{Keq} / \mathrm{ha}$ per annum. In Scandinavia, lumbering sites have sustained such enhanced losses for at least three centuries with no apparent ill effects (Rosenqvist, 1980). The current practice of removing the whole tree will probably double the rate of base nutrient removal (Likens et al., 1978; and Rosenqvist, 1980).

Thus, the biogeochemistry of acid forest soils is one where some acceleration in losses of base nutrients causes no apparent harm. Weathering of minerals in watersheds with very acid soils ranges from 1 to $2 \mathrm{Keq} / \mathrm{ha}$ per annum (Stuanes, 1980), which is slow relative to weathering in less acid soils (Jenny, 1941; Birkeland, 1974; and Andersson et al., 1980) and sets the limit of nutrient losses, both natural and man-induced, that can be replaced by mineral weathering.

Some researchers insist that $\mathrm{H}^{+}$from acid rains is leaching one charge of cations for each charge of $\mathrm{H}^{+}$ (Gjessing et al., 1976; Galloway et al., 1980a and b; Thompson et al., 1980; and Wright and Johannessen, 1980). However, such an assumption does not explain their own research results. Cation losses in rivers in eastern Canada are least where inputs of acid rain are greatest (Thompson et al., 1980). In the Norwegian watersheds (Gjessing et al., 1976; and Wright and Johannessen, 1980), strict application of the assumption of equivalent leaching implies that there would be no cation loss without acid rain since losses of cations are equivalent to inputs of $\mathrm{H}^{+}$in acid rain. In the Adirondacks (Galloway et al., 1980a) we would have the physically impossible circumstance of negative concentrations without acid rain since the rate of cation export (including $\mathrm{H}^{+}$) can be less than $\mathrm{H}^{+}$inputs in acid rain.

Soils with higher base saturation are more easily leached by acid (Wiklander, 1973/74, 1975, and 1980) than are acid soils. If mineral weathering and biological cycling cannot keep pace with acid leaching, these soils will become more acid (Figure 3). This acidification would eventually decrease weathering and biological cycling of bases, shifting soil evolution to a more acidic pathway.
Soils of naturally moderate base saturation are geographically located between soils with low base saturation in humid climates, and soils with high base saturation in prairies and deserts. In the United States, these soils are found in western New York, the Midwest, and the Mississippi Valley. Coarse-textured soils with low cation exchange capacity, relatively slow mineral weathering, rapid percolation, and supporting poor forest growth are the most likely to be affected by acid rain.

Recently abandoned agricultural lands in the Northeast have moderate base saturation because of past additions of lime and fertilizer, and may be potentially sensitive to acid rain. However, they are evolving naturally into acid forest soils that are insensitive to acid rain, as did land abandoned in the Northeast over the last two centuries.

Managed agricultural soils are not likely to be acidified by acid rain (Frink and Voigt, 1976). Farmers must counter the normal course of nutrient leaching, plus removal by harvesting, acidification by fertilizer elements $(\mathrm{N}, \mathrm{P}, \mathrm{S})$ and decomposition of plant residues through addition of tons per acre of lime (Table 2). Additions of $\mathrm{N}$ and $S$ in rain at rates equivalent to 20 to $50 \mathrm{lbs}$. of lime per acre will have no impact on the acidity of such soils. Moreover, the sulfur in rain may actually be beneficial. The first nation-wide study of acid rain was conducted in Sweden where agriculture was reported to suffer widely from sulfur deficiency. At that time, sulfur deficiency was least severe in areas receiving the most acid rain (Johansson, 1959).

Nutrients in rain may also be important in acid forest soils because nitrogen fixation is relatively slight. Indeed, studies in southern Norway show that about $90 \%$ of the $\mathrm{N}$ in acid rain is retained in the watershed (Gjessing et al., 1976). Since sulfur in rain generally exceeds the requirements of forests, sulfur is a prominent anion in leachate from acid forest soils. The nutritional benefits from $\mathrm{N}$ and $\mathrm{S}$ in acid rain appear to be site specific (D.W. Johnson et al., 1982).

Concern has been expressed that leaching of exchangeable nutrient cations may affect forest productivity. Future studies should recognize that exchangeable cations are only a small fraction of available plant nutrients in forest soils (Mortvedt et al., 1972; Stone, 1975; and Adams and Boyle, 1982). Such studies should also recognize that physical site characteristics, such as differences in soil texture, drainage, depth of soil, depth of watertable, and aspect, are generally recognized as more important variables in forest productivity than are differences in soil chemistry. It seems unlikely that acid rain would significantly alter physical site characteristics.

In conclusion, both chemistry and biology predict that present day acid rain will not measurably enhance leaching of nutrient cations from the acid forest soils of the Northeast, southeastem Canada, and Scandinavia. Indeed, it is difficult to envision acid rain damaging ecosystems that are producing environments more acid than acid rain. However, misconceptions about the nature of soil acidity sustain the notion that acid rain is increasing acidification of soil and water. These are dealt with in the next section. 


\section{Acidification of Soil and Water}

Acid rain is believed to be causing widespread acidification of soil and water in the northeastern United States, southeastern Canada and southern Scandinavia. Alpine-like landscapes with their thin, organic-rich soils developed on mountain slopes from granitic parent materials under coniferous and heath vegetation are thought to be especially vulnerable. Susceptibility of these soils to acidification is attributed to their lack of "basic" materials capable of rapidly neutralizing acid rain. Also, steep slopes act to minimize contact time between acid rain and neutralizing materials in the soil, which is believed to be particularly important for the initial portions of heavy rains and rapid snowmelts that are often more acid than the later periods of the storm or melt. Accordingly, it is said that alpine-like streams and lakes are being acidified by acid runoff: acid falling directly in lakes and streams is considered a minor but contributing factor (Overrein et al., 1980; and Seip, 19S0a).

The very existence of acid runoff is widely accepted as proof that acid rain is acidifying soil and water (N.M. Johnson et al., 1972; and Likens, 1972). Summaries of the first four years of the Norwegian Acid Precipitation Project (SNSF) attributed acid runoff solely to acid rain (Gjessing et al., 1976; and Leivestad et al., 1976). Even the existence of acid soils has been considered evidence of acidification by acid rain. Odén (1976) attributes the extremely acid podzols in southern Scandinavia to acidification by acid rain (Figure 5). However, the $\mathrm{pH}$ of podzol humus is lower than that of acid rain; also, acid rain is a relatively recent phenomenon. It is difficult to see how acid rain could lower the $\mathrm{pH}$ of these soils below that of the rain, particularly over a relatively short period of time, with resultant large increases in their exchange acidity (Bergseth, 1977).

Acidification of soil and water in mountainous environments is said to herald the future of the lowlands as acid rain eventually wears down the greater acidneutralizing capacity of these thicker soils. Accordingly, the Northeast Acid Rain Task Force (Bridge and Fairchild, 1981) estimates that $44 \%$ of Connecticut's lakes will be acidified if acid rain is not stopped. The $1 n-$ stitute of Ecology in Indiana (Loucks et al., 1982) places this figure at $100 \%$.

Soil maps of New York, New England, Canada and Scandinavia (Jenny, 1941, p. 182; Clayton et al., 1977; Cline and Marshall, 1976; and Låg, 1979) show that the areas considered to be affected severely by acid rain correspond to the natural distribution of extremely acid podzols and peaty soils. The coincidence between the presumed effects of acid rain and the location of acid soils grows stronger with the realization that thin,

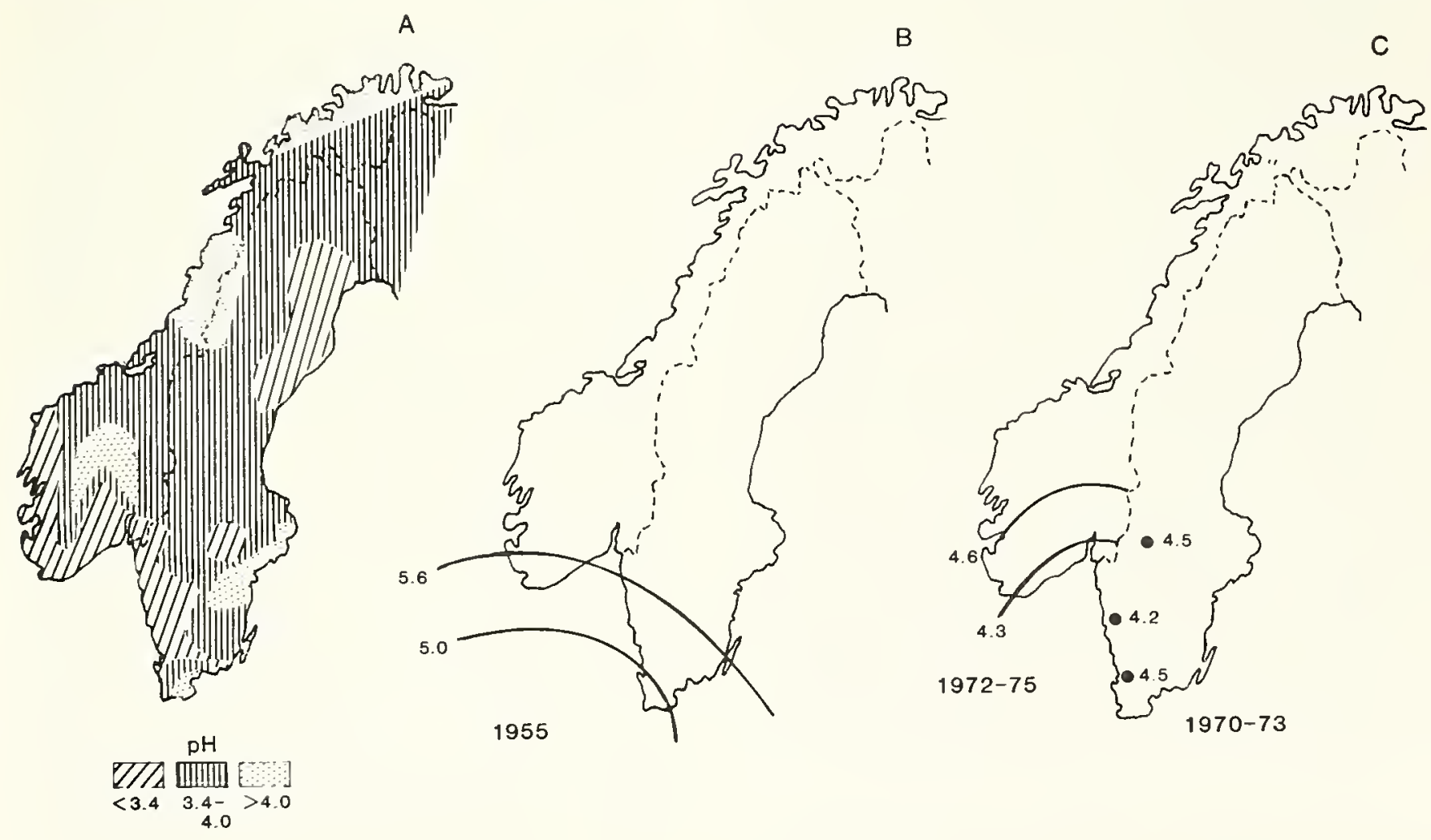

Figure 5. Comparison of pH of Scandinavian Soil and Precipitation. (A from Odén, 1976; B from Dovland et al., 1976; and C from Hileman, 1982.) 
organic-rich mountain soils are generally even more acid than the podzols developed on deeper materials, a longknown fact shown by Wherry's (1923) literature review. Comparison of soil $\mathrm{pH}\left(\mathrm{H}_{2} \mathrm{O}\right)$ data predating regional acid rain confirms this: analysis of over 200 samples by Heimburger (1934) of forest soils from the upper slopes of the Adirondacks, the White Mountains of New England, and the Laurentians of southeastern Canada show that these soils are more acid, with the pH averaging in the low $3 \mathrm{~s}$, than the thicker soils of the lower slopes and valleys (Lunt, 1932 and 1948; Young, 1934; Brown and Byers, 1938; Chandler, 1939; Richard and Chandler, 1943; and Table 1). Likewise, Caine (1931) demonstrated similar relationships between soil $\mathrm{pH}$ and topograpliy for the Great Smoky Mountains of North Carolina and Tennessee. The recently completed 80,000 sample national soil survey in Sweden* shows that humus developed over bare bedrock is more acid than that of thin soils, which in turn is more acid than that of thick soils. The Swedish soil survey also shows thick humus soils to be more acid than thin humus soils, and humus of very rocky soils to be more acid than less rocky soils (Troedsson, 1980). Depth of mineral soil decreased and depth of humus and acidity increased with altitude on the undisturbed forested slopes of Camels Hump in the Green Mountains of Vermont (Siccama, 1968). Indeed, these thin mountain soils and very rocky soils naturally develop such thick humus layers that they can be classified as organic soils (Heimburger, 1934; Diebold, 1941; Lutz and Chandler, 1946, p. 183; Oosting and Billings, 195I; Witty and Arnold, 1970; Lewis and Lavkulich, 1972; Bohn, 1976; Clayton et al., 1977; and Braekke, 1981).

These organic-rich soils can be viewed as being similar to the uppermost acid portion of podzol soils (Table 1); the major difference is that they are generally even nore acid, have thicker humus, and the bleached $A_{2}$ horizon may be replaced by humus-enriched mineral soil horizons, i.e. $A_{1}$ and $B_{h}$ horizons. Siccama (1974) shows that the $\mathrm{pH}$ of the $\mathrm{B}$ horizon (probably $\mathrm{B}_{\mathrm{h}}$ ) decreases from 5.4 to 3.7 with increasing altitude on Camels Hump. Thus, there is a topographic gradient in soil properties and acidity, where leached upland soils resemble acid A horizons, and lowland soils are zones of accumulation resembling less acid B horizons. This sequence of soil properties is known as a geochemical catena, with the podzol soils on the forested mountains of Norway serving as a classic example (Glazovskaya, 1968 and 1970). A gradient of stream acidity paralleling such a catena should not be surprising, because the factors thought to make runoff susceptible to acidification by acid rain are the same factors that make runoff susceptible to acidification by acid soil. Such gradients in acidity have been observed in the Northeast, but they have been

* Method of pH $\left(\mathrm{H}_{2} \mathrm{O}\right)$ determination was not reported. Scandinavian soil scientists commonly use very large water-to-soil ratios to determine soil pHI. Consequently, their reported $\mathrm{pH}\left(\mathrm{H}_{2} \mathrm{O}\right)$ values are somewhat less acid than those reported by American and Canadian soil scientists for similar soils because of the dilution effect. attributed entirely to acid rain (N.M. Johnson, 1979; and N.M. Johnson et al., 1981).

The report of the first four years of the SNSF-project also confused the effects of acid rain with those of acid soil. Several Scandinavian scientists pointed out that runoff from acid soil will be acid regardless of the $\mathrm{pH}$ of rain (Wiklander, 1973/74 and 1975; Låg, 1976; Rosenqvist, 1978 and Rueslåtten and Jørgensen, 1978). Rueslåtten and Jørgensen (1978) showed that even small patches of moss colonizing exposed granitic bedrock in southern Norway acidify runoff substantially. For example, these patches of moss and their underlying humus acidified snowmelt, from its original $\mathrm{pH}$ of 4.9 to 5.1 , down to $\mathrm{pH}$ 3.9. After traveling about 50 meters, the $\mathrm{pH}$ of the meltwater rose to the mid-4's because of relatively rapid reaction with exposed grains of feldspar. Summer rainfall of $\mathrm{pH} 4.5$ also produced runoff with $\mathrm{pH}$ values in the mid- 4 's.

A review of the literature by Wiklander (1946) shows that additions of neutral salts generally acidify leachate from acid soils more effectively than do strong acids at the concentrations present in acid rain. This so-called "salt-effect" was discussed earlier under Measurements of Soil Acidity. Wiklander (1973/74 and 1975) also notes that basic cations in rain prevent reduction of the base saturation of soils and thus prevent acidification (Figure 3 ). Hence, he concluded that the interaction of basic cations with acid soil is more likely to acidify runoff than the strong acids of acid rain.

Rosenqvist (1978) describes acidification of runoff in terms of hydrology and soil acidity. Runoff from rapid snowmelts and heavy rains moves primarily through the upper and most acid horizons (Table 1) and hence, is more acid than runoff from gentle rains or slower snowmelts which percolates through near-neutral subsoil. Rosenqvist states that critical examination of SNSF data shows that rainstorms of similar intensity produce runoff of similar acidity regardless of the $\mathrm{pH}$ of the rain itself. Rosenquist (1978) also points out that areas of Scandinavia believed to be affected by acid rain are areas where there are also naturally acid waters. Patrick et al. (1981) remind us that this is also true in North America. Rosenqvist (1978) attributed the increasing acidification of such waters to increasing soil acidity resulting from changes in land use, a subject we shall later examine in detail.

More recent research in the SNSF-project addresses a number of the earlier criticisms. Abrahamsen et al. (1978) studied the effects of simulated acid rain on a large expanse of bedrock where about $20 \%$ of the surface was covered with lichens. The simulated rain was collected and analyzed after traveling about 40-50 feet over the rock surface. The $\mathrm{pH}$ of the runoff was found to depend on both the neutral salt and the acid content of the simulated rain. The $\mathrm{pH}$ of runoff from "rain" at $\mathrm{pH} 5$ was initially 4.1-4.3 and increased with time to $\mathrm{pH}$ 4.6-4.7. When neutral salts were omitted from the "rain," the $\mathrm{pH}$ of the runoff rose quickly to 5. Application of simulated rain with $\mathrm{pH} 4.3$ resulted in runoff of $\mathrm{pH} 4.3$, which is approximately the $\mathrm{pH}$ of rain observed in the 
southernmost tip of Norway in the late 1970's (Overrein et al., 1980, p. 24).

In laboratory experiments, a $4 \mathrm{~cm}$ (1.6 in) thick layer of mor humus was leached at various rates $(2.4 \mathrm{in} / \mathrm{hr}$ to 7 in/day) with water acidified to $\mathrm{pH} 3,4$ and 5 and with equivalent concentrations of $\mathrm{NaCl}$, i.e. $10^{-3} \mathrm{M}, 10^{-4}$ $\mathbf{M}$, and $10^{-5} \mathbf{M}$. Rapid leaching with solutions at $\mathrm{pH} 4$ and 5 gradually increased the $\mathrm{pH}$ of the leachate, but solutions of $\mathrm{pH} 3$ gradually decreased the $\mathrm{pH}$. If the humus stood overnight, the leachate from the treatments at pH 4 and 5 became more acid, while the leachate from the treatment at $\mathrm{pH} 3$ became less acid. Rapid leaching with $10^{-4}$ and $10^{-5} \mathrm{M} \mathrm{NaCl}$ produced slightly more acid leachate than treatment with $\mathrm{H}_{2} \mathrm{SO}_{4}$ at $\mathrm{pH} 4$ or $\mathrm{pH}$ 5 , while $10^{-3} \mathrm{M} \mathrm{NaCl}$ produced about the same acidity as $\mathrm{H}_{2} \mathrm{SO}_{4}$ at pH 3 (Overrein et al., 1980, p. 55). It is worth noting that rain in coastal areas of Norway may average about $10^{-3} \mathbf{M}$ salt (Låg, 1968).

Lunt (1941) leached forest soil materials in Connecticut with distilled water for two weeks at a rate equivalent to nearly $600 \mathrm{in} / \mathrm{yr}$. The $\mathrm{pH}$ of leachate increased gradually and color and conductivity decreased with leaching. If the soil stood overnight the leachate returned to nearly its original $\mathrm{pH}$, color and conductivity. These results strongly suggest that acidification occurred by dissolution of organic acids. Rosenqvist (1978) noted similar recovery of acidity. Humus leached with the equivalent of 50 to 150 years of $\mathrm{pH} 8$ precipitation in 3 days resulted in a decrease in the acidity of the leachate of only about $0.5 \mathrm{pH}$ unit.

These experiments confirm that humus has an enormous acidifying and buffering capacity. Rapid leaching lessens the control exerted by humus, with treatments at pH 4 or higher actually raising the $\mathrm{pH}$. However, the soil soon returns to its original more acid condition.

In other SNSF-project studies, thin mountain soil and podzols were placed in lysimeters and leached with synthetic rain at normal rates for three to five years. Treatments at $\mathrm{pH} 4$ or higher produced no significant differences in leachate chemistry other than an increase in $\mathrm{SO}_{4}=$. Treatments at $\mathrm{pH} 2$ and 3 increased leaching and acidity (Abrahamsen, 1980; Abrahamsen and Stuanes, 1980; and Stuanes, 1980). The acidity of the leachate varied due to both season and drought. These effects can be as pronounced as treatment with rain at $\mathrm{pH} 2$ (Abrahamsen, 1980; and Abrahamsen and Stuanes, 1980), nicely illustrating the magnitude of the "salt effect" on acid soils. Thus, soils are not only acid sinks but can be acid sources as well.

Given the heterogeneity of soil, landscapes, and hydrology, Seip et al., (1979a) concluded that it is difficult to observe the effects of acid rain even in watersheds as small as $0.1 \mathrm{~km}^{2}$ (about 25 acres).

Because the effects of acid soil are confounded with those of acid rain in most watersheds, further studies in the SNSF-project were conducted in small, bare bedrock catchments. Southern Norway has an abundance of such landscapes, caused in part by the reduction in elevation of the tree line and the severe erosion from several thousand years of cutting, burning, and grazing
(Rosenqvist, 1978; and Overrein et al., 1980, p. 102). More locally, examples of man-induced tree line and exposed bedrock are found in the White Mountains (Monahan, 1933; Baldwin, 1977; and Bormann and Likens, 1979, pp.. 188-189) and the Adirondacks (Eschner and Satterlund, 1966).

Six mini-catchments were established in the Storgama watershed in southernmost Norway. The bedrock is principally granite and the soil cover is shallow, with about $30 \%$ of the total watershed area exposed as bare rock. The mini-catchments ranged in size from $30 \mathrm{~m}^{2}$ to $264 \mathrm{~m}^{2}$. From $46 \%$ to $74 \%$ of the catchments are exposed bedrock (Seip et al., 1979a). Because of the shallow soil, very small size, and large percentage of exposed bedrock, these catchments represent the worst case hypothesis. The effects of acid rain should be most easily demonstrated here.

On average, runoff from acid rain in these minicatchments was twice as acid as the rain. Only with the heaviest rains in the smallest basins did the $\mathrm{pH}$ of rain measurably influence the $\mathrm{pH}$ of runoff. Exchangeable $\mathrm{H}$-ions in the patches of thin soil ranged from 50 to 200 times the annual inputs of acid rain (Seip et al., 1979a).

Rosenquist's (1978) hypothesis that runoff chemistry is controlled principally by soil and that snowmelt will be acid regardless of the $\mathrm{pH}$ of snow was also tested in these mini-catchments. The snowpack in both 1978 and 1979 had a mean pH of 4.3. In 1979 snowpack was neutralized to about $\mathrm{pH} 7$ with $\mathrm{NaOH}$. Runoff from both snowpacks had a high initial flush of acidity followed by a similar decrease in acidity. Runoff from the neutralized snowpack was slightly more acid (Seip et al., 1980).

In another experiment, artificial rain at $\mathrm{pH} 3.85$ was sprayed on mini-catchments and acidified runoff by 0.2 to $0.4 \mathrm{pH}$ units. However, the authors indicated that further research would be necessary to determine whether rain at $\mathrm{pH} 3.85$ could acidify runoff from an entire watershed (Seip et al., 1979b). These experiments were not conducted since the SNSF-project terminated in 1979 .

Some believe that forest soils in the northeastern United States freeze in winter and thus exert little control over the chemistry of snowmelt, although this is inconsistent with the belief that aluminum is dissolved by acid snowmelt. However, studies at Hubbard Brook show that runoff does not flow overland (Likens et al., 1977). Rarely is even a small fraction of the area of the forest floor frozen, and this is usually restricted to soil mounds during the coldest winters with no snowcover (Hart et al., 1962). Hydrologic studies in northern Vermont show that up to $50 \%$ of all runoff occurs during spring snowmelt, with a large component of near-surface interflow. This is because waterlogging limits deep percolation into soil (Pionke et al., 1982). Thus, the Rosenqvist hypothesis seems valid for the Northeast as well.

The final report of the SNSF-project (Overrein et al., 1980) acknowledges that runoff from acid soils will be acid and can affect the alkalinity and $\mathrm{pH}$ of streams and lakes depending upon hydrology and the ionic strength of the rain. The report also notes that acidification of 
streams and lakes predates acid rain, and that acidification of soils due to changes in land use can contribute to acidification of freshwaters. Also, the magnitude and extent of acidification of lakes is less than previous reports because of the scarcity and uncertainties of early data and the large seasonal and spatial variation in the $\mathrm{pH}$ of lakes.

The magnitude of acidification of lakes in the Adirondacks may also be less than previously reported. Schofield (1976a and b) reported that only $4 \%$ of the lakes at high altitudes sampled in the 1930's were less than pH 5, but that in the mid-1970's about $50 \%$ were less than $\mathrm{pH}$ 5. Pfeiffer and Festa (1980) have examined the colorimetric method used in the studies and found that it gave $\mathrm{pH}$ readings up to 1.5 units higher than do present methods. They resampled the lakes in 1979, and, using the old colorimetric method, found that only about $9 \%$ had $\mathrm{pH}$ values less than 5 . There is also evidence suggesting that these lakes were acid and had declining fish reproduction some fifty years ago. A report sponsored by the New York State Department of Environmental Conservation (1982, p. 49) indicates that acidification of these lakes may be due to long-term natural processes accelerated by acid rain, and stresses the need to quantify these two processes.

Although there is now agreement that acid soils can create acid runoff, misconceptions about the nature and measurement of soil acidity continue to create the notion that acid rain is primarily responsible for acidifying runoff. One misconception concerns anion leaching. Acid rain has increased the inputs of $\mathrm{SO}_{4}{ }^{-}$and $\mathrm{NO}_{3}{ }^{-}$ to landscapes. Much of the $\mathrm{NO}_{3}{ }^{-}$is rapidly taken up by vegetation and is generally not considered important in the leachate from acid soils (D.W. Johnson et al., 1982). Most acid in acid rain is $\mathrm{H}_{2} \mathrm{SO}_{4}$, and $\mathrm{SO}_{4}=$ moves through thin, organic-rich soils and into drainage waters because humic acids occupy reactive sites that can otherwise immobilize $\mathrm{SO}_{4}=$. Thus, to maintain charge neutrality, sulfate is asserted to enhance cation leaching on a 1:1 charge equivalent basis (Overrein et al., 1980; and Seip, 1980a).

Wiklander (1973/74) showed by theory and experiment that cation leaching is not enhanced by anions in acid rain. Anions only alter the ionic strength and hence alter activity coefficients, an effect which is negligible. Other soil and watershed studies have failed to demonstrate enhanced movement of cations, although there has usually been a significant increase in the flux of $\mathrm{SO}_{4}=$ in drainage water and leachate. Despite lack of evidence of enhanced cation leaching, the observed increase in flux of sulfate continues to be used to defend the conclusion that acid rain increases the leaching of $\mathrm{H}^{+}$and other cations. Others, observing that leaching of basic cations $(\Delta M)$ is small relative to additions of hydrogen ions $(\Delta H)$, i.e. $\Delta M / \Delta H<1$, argue that acid soils buffer poorly against additions of $\mathrm{H}^{+}$ions and therefore, most $\mathrm{H}^{+}$added to acid soil moves quickly through it as $\mathrm{H}_{2} \mathrm{SO}_{4}$ (Overrein et al., 1980; and Seip, 1980a).

However, it is well known that acid soils and especially acid humus strongly buffer water against changes in $\mathrm{pH}$ (Figure 1). Acid humus is a strong buffer because its acidity is due to humic acids whose dissociation (Figure 2, pathway 2b) is controlled by $\mathrm{pH}$. Added $\mathrm{H}^{+}$ hinders dissociation of humic acids and decreases their solubility (Hayes and Swift, 1978, p. 281; Ghosh and Schnitzer, 1980; and Ritchie and Posner, 1982), with the net result that increased $\mathrm{SO}_{4}{ }^{=}$flux should be compensated for by decreased humate flux. Likewise, there should be a tradeoff between $\mathrm{H}^{+}$from acid rain for $\mathrm{H}^{+}$ from humic acids:* $\mathrm{H}^{+}$now remaining associated with organic acids as a result of acid rain is converted to $\mathrm{CO}_{2}$ and $\mathrm{H}_{2} \mathrm{O}$ with the rest of the humic acids (Figure 2, pathway 2c). An analogous phenomenon occurs with acid soil development where increasingly acid leachate from humus increasingly hinders the dissociation of $\mathrm{H}_{2} \mathrm{CO}_{3}$ (Figure 2, pathway 2c) to the point where it no longer contributes to acid mineral weathering.

The second misconception is that rate of production of acid by soil is equal to rate of mineral weathering and, in environments where neutralization of $\mathrm{H}^{+}$is incomplete, to the rate of acid export as well (Figure 2, pathways 3 and 4 ). As discussed earlier, as acid soils develop, more and more acidity is lost as $\mathrm{CO}_{2}$ and $\mathrm{H}_{2} \mathrm{O}$ (Figure 2 , pathway 2) and rates of weathering and cation denudation decrease to very low levels. If the only sink for $\mathrm{H}^{+}$ was neutralization by mineral weathering or its byproducts, acid rain would indeed have a very serious impact on acid soils. However, this conceptual model of acidity ignores the enormous acid sink provided by humic materials (Figure 2, pathway $2 b$ ) and the ability of humic acids to compensate for additions of $\mathrm{H}_{2} \mathrm{SO}_{4}$. Ironically, little attention has been given this biological effect on acidity beyond Rosenqvist (1980) alluding to such a possibility.

Placing acid rain in perspective with other sources and sinks of acid in soil (Figure 1) explains why net ion exports in some acid soil watersheds in the Northeast, Canada and Norway are about as low as inputs of acid rain (Gjessing et al., 1976; N.M. Johnson, 1979; Galloway et al., 1980a; Kerekes, 1980; Thompson et al., 1980; and Wright and Johanessen, 1980). It also explains why numerous soil studies have shown no acidification or enhanced leaching. Finally, it explains the observation that some Scandinavian lakes originally colored by humic materials are becoming clearer and contain less dissolved organic carbon. This had previously been attributed solely to precipitation of humic acid in soil and water by iron and aluminum dissolved by acid rain (Almer et al., 1978; and Dickson, 1980). However, the amounts of dissolved aluminum in acid soils are enormous (Pearson and Adams, 1967; and Figure 3) and such an acid rain effect would be trivial. Indeed, if acid rain did nothing but dissolve aluminum, hundreds of years of rain at $\mathrm{pH} 4$ would be required to dissolve the amounts

\footnotetext{
* During preparation of this manuscript, this hypothesis has been verified, at least in part, by research presented at the 74th Annual Meeting of the American Society of Agronomy, November 28December 3, 1982 by J.G. McColl, B.A. Browne and M.K. Firestone, and by unpublished data of P.J. Isaacson and E.C. Krng.
} 


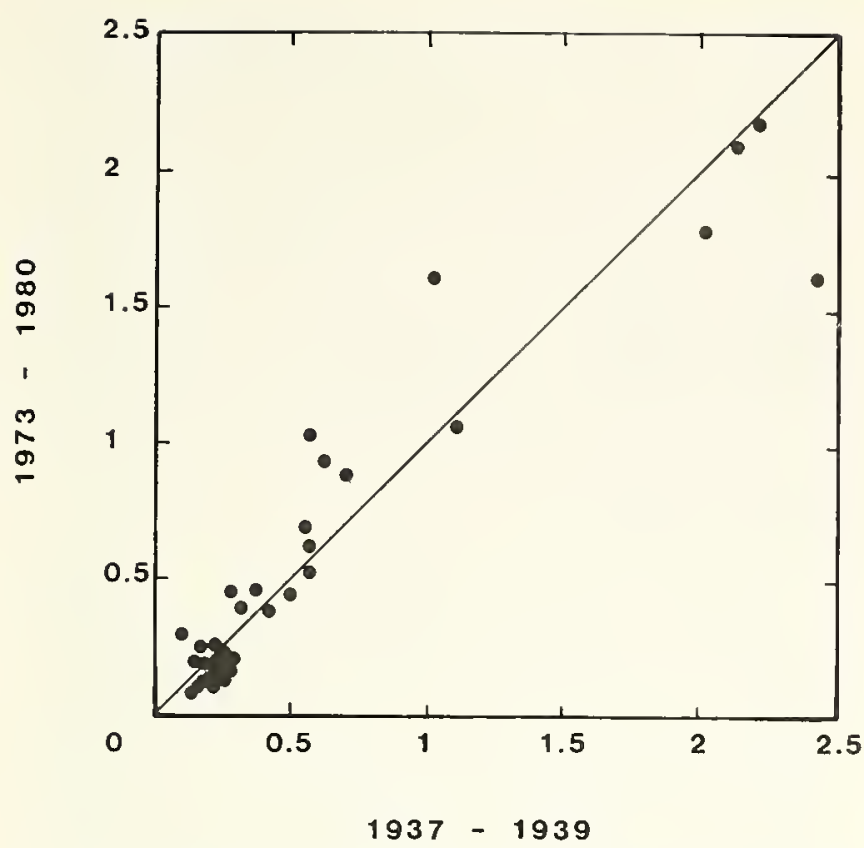

Figure 6. Alkalinity in meq/l for 35 Connecticut Lakes. Data from Norvell and Frink, 1975 and Frink and Norvell, 1984.

of aluminum found in these acid soils. There simply is not enough acid in acid rain to measurably increase the amount of dissolved aluminum.

The reduction of humic acid in lakes appears to be one of the few measurable and potentially undesirable effects of acid rain. Humic acids strongly combine with aluminum and other metals that can otherwise be toxic to organisms. These humic acids also contribute to the buffering capacity of water. The importance of these effects needs further study.

Despite the attention given to acidification of lakes and streams, it is important to realize that most of the waters in areas said to be sensitive to acid rain are not becoming more acidic. Acid waters are almost exclusively small headwater streams and lakes receiving high proportions of near-surface runoff. Waters of the lower slopes and lowlands are usually not acidified. N.M. Johnson (1979, and 1982) notes that these lakes and streams receive a large proportion of their water from near-neutral subsoils and underlying geologic materials where contact time is also greater. Because even granite has enormous acid-neutralizing capacity (Table 2), Johnson concludes that such waters will not be significantly acidified by acid rain in the foreseeable future.

Similarly, we do not expect that natural soil acidification will eritically acidify drainage to lakes and streams in deep granitic soils in lowland settings typical of Connecticut. References cited earlier indicating that half to all of Connecticut's freshwaters are highly susceptible to acidification by acid rain are not supported by our experimental data (Figure 6), or by Tobin's limited survey of the $\mathrm{pH}$ of municipal water supplies in Connecticut (Tobin, 1980).

Acid rain falling directly on lake surfaces can contribute to their acidification. Ignoring biology and interactions between water and sediments, the alkalinity (chiefly bicarbonate) of lakes is a measure of their ability to resist acidification. Alkalinity is supplied in large part by weathering reactions in the watersheds, as well as by aquatic sediments and biological activity. In watersheds with granitic soils, rates of weathering are very low, and, consequently, so is the alkalinity of their drainage waters. In such areas, for lakes with small ratios of drainage area to lake area, direct inputs of acid rain may exceed inputs of alkalinity from the watershed. One lake has been found in Canada where the lake itself occupies $42 \%$ of the watershed (drainage area to lake area ratio of 1.4) and its acidification by acid rain is reasonably well documented (Dillon et al., 1978). For low alkalinity lakes with drainage area to lake area ratios of 3-7, inputs of acid rain may be equivalent to a measurable fraction of the alkalinity supplied by the watershed. The relative contribution to acidification of these types of lakes by acid soil and acid rain must be assessed lake by lake. While acidification by direct preeipitation is generally thought to be a minor factor (Overrein et al., 1980; and Seip, 1980a), a Norwegian limnologist noted that for waters naturally acidified to a critical level, a small increase in acidity "may have fatal consequences (Dahl, 1927)" (Overrein et al., 1980, p. 36).

\section{Dissolution and Leaching of Aluminum}

The cation exchange sites of acid siliceous soil materials below $\mathrm{pH} 5$ are nearly completely saturated with ionic aluminum. While podzols and associated peaty soils are the most acid major soil groups in the world, other major soil types are sufficiently acid to contain considerable quantities of dissolved aluminum. For example, oxisols and ultisols cover nearly three-quarters of the Amazon River Basin, and are so aeid that their natural vegetation is reported to suffer from aluminum toxicity (Sanchez et al., 1982).

Because of the importance of aluminum in soil, not only in terms of its great abundance, but also because of its role in soil acidity, toxicity, and interaction with nutrients, as well as its role in soil genesis, the chemistry of aluminum in aqueous systems has been studied extensively by soils chemists. A brief and arhitrary list of important studies and reviews published in English includes: Burgess and Pember (1923); Hardy (1926); Joffe and McLean (1928a and b); Joffe (1930); Mattson and Hester (1933); Boratyński and Mattson (1939); Bower and Truog (1940); Lindsay et al. (1959); Hsu and Rich (1960); Jenny (1961); Frink and Peech (1962); Jackson (1963); Sehnitzer and Skinner (1963a and b); van Schuylenborgh and Bruggenwert (1965); Pearson and 
Table 4. Comparison of Acid Rain and Snow on Mount Moosilauke Forest Floor Leachate.*

\begin{tabular}{|c|c|c|c|c|}
\hline \multirow[t]{2}{*}{ Sample } & \multirow[t]{2}{*}{$\mathrm{pH}$} & \multicolumn{3}{|c|}{ Concentration $(\mu \mathrm{eq} / 1)$} \\
\hline & & $\mathrm{H}^{+}$ & $\mathrm{Al}^{\mathrm{*} *}$ & Strength ${ }^{* * *}$ \\
\hline "Unpolluted" water & 5.6 & 2.5 & - & - \\
\hline Mean snowpack & 5.04 & 9.1 & - & $23 \dagger$ \\
\hline Acid Rain & 4.08 & 83 & - & 115 \\
\hline Throughfall & 4.02 & 95 & 5 & 201 \\
\hline \multicolumn{5}{|l|}{ Throughfall Forest } \\
\hline Floor Leachate & 4.04 & 91 & 54 & 219 \\
\hline \multicolumn{5}{|l|}{ Snow Forest Floor } \\
\hline Leachate & 4.12 & 79 & 60 & 205 \\
\hline Spring water & 4.66 & 22 & 67 & 163 \\
\hline
\end{tabular}

* From Cronan, 1978, pp. 72, 73, and 114.

** Al species assumed to $\mathrm{Al}^{+3}$

*** lonic strength $=\mathrm{H}^{+}+\mathrm{Ca}^{+2}+\mathrm{Mg}^{+2}+\mathrm{K}^{+}+\mathrm{Na}^{+}+$ $\mathrm{NH}_{4}^{+}+\mathrm{Al}^{+3}+\mathrm{Fe}^{+2}+\mathrm{Mn}^{+2}$

$+\mathrm{NH}_{4}{ }^{+}, \mathrm{Al}^{+3}, \mathrm{Fe}^{+2}$, and $\mathrm{Mn}^{+2}$ not determined.

Adams (1967); and Thomas (1977). Despite the enormous literature on the reactions of ionic aluminum in naturally acid soils, the mere presence of soluble aluminum in soil and water at $\mathrm{pH} 5$ or less is widely believed as proof that acid rain is dissolving aluminum (N.M. Johnson et al., 1969, 1972 and 1981; Wright et al., 1975; Gjessing et al, 1976; Leivestad et al., 1976; Wright and Henricksen, 1978; and Henricksen and Seip, 1980). The rationale behind this assumption is that $\mathrm{H}_{2} \mathrm{CO}_{3}$ is responsible for chemical weathering and leaching of earth materials. Thus, waters more acid than $\mathrm{pH} \sim 5.6$ that contain dissolved aluminum must be the result of acid rain. While agreeing with this principal assumption, Cronan and Schofield (1979) and N. M. Johnson et al. (1981) recognize that organic acids also have a role in acidification and mobilization of aluminum.

Cronan and Schofield (1979) have been widely cited and credited by Cowling (1982) as having made a principal and historic discovery that aluminum ions are leached from soil into lakes and streams by acid rain at concentrations toxic to fish. This discovery is based on observations that mobilization of aluminum is considerably less in "pristine" sites in New Mexico (studied by Graustein, 1981) and Washington (studied by Ugolini et al., 1977a and b) than in "polluted" sites at Mount Moosilauke in New Hampshire studied by Cronan (1978). Although solution chemistry and some soil properties were determined at this latter site in the White Mountains, soil pH apparently was not (Cronan, 1978; Cronan et al., 1978; and Cronan and Schofield, 1979). In New Mexico, the pH $\left(\mathrm{H}_{2} \mathrm{O}\right)$ of the soil was 6.6 to 7.2 (Graustein, 1981) and in Washington, the $\mathrm{pH}\left(\mathrm{H}_{2} \mathrm{O}\right)$ of the soil was' $\sim$.5 (Ugolini et al., 1977a and b). Thus, these soils are considerably less acid than White Mountain forest soils where, according to Hoyle (1973), the $\mathrm{pH}\left(\mathrm{H}_{2} \mathrm{O}\right)$ of humus may be less than 3 , the surface mineral horizons vary from $\mathrm{pH}\left(\mathrm{H}_{2} \mathrm{O}\right) 3$ to 4 , and the subsoil is $\mathrm{pH}$ $\left(\mathrm{H}_{2} \mathrm{O}\right) 4$ to 5.5. Data for nearby Hubbard Brook soil, 8 miles to the southeast of Mount Moosilauke, where soils are developed from the same parent material (Cronan, 1978 , p. 25; and Johnson et al., 1968) but under northern hardwood rather than coniferous forest, are in Table 2. Despite the fact that all three locations are similar subalpine coniferous forest ecosystems in humid temperate climates, it is not surprising that concentrations of ionic aluminum are lower in the less acid "pristine" sites in New Mexico and Washington, because the soils are naturally less acid than those of the "polluted" sites in New Hampshire.

Analyses of leachate from the same New Hampshire soil treated with water varying in $\mathrm{pH}$ would help determine whether acid rain is acidifying leachate and dissolving aluminum. Fortunately, Cronan (1978) presents data that can be used for this purpose (Table 4). Mean forest throughfall to the soil was extremely acid, with $95 \mu \mathrm{eq}$ $\mathrm{H}^{+} / \mathrm{l}$ ( $\mathrm{pH} 4.01$ ), while mean snowpack contained only $9.1 \mu \mathrm{eq} \mathrm{H}^{+} / 1(\mathrm{pH} 5.04)$, and is similar in acidity to "unpolluted" rain with $2.5 \mu \mathrm{eq} \mathrm{H}^{+} / \mathrm{l}$ (pH 5.6). Table 4 shows only small differences between aluminum in leachate from the acid throughfall with ionic strength $201 \mu \mathrm{eq} / \mathrm{l}$, and from the less acid snowmelt with ionic strength $23 \mu \mathrm{eq} /$. Clearly, acid rain is not increasing leaching by the difference of $83-95 \mu \mathrm{eq} \mathrm{H}^{+} / \mathrm{l}$ that reaches the forest floor, nor is the rain increasing acid mineral weathering and dissolving aluminum by a similar amount.

The small differences in composition of the leachate from rain and snowmelt probably reflect the differences in hydrology of Cronan's sites and in analysis of the data for throughfall and snowmelt. From late April to early May leaching of snowmelt occurs for a good part of the day so that the average composition of the leachate is probably representative of individual leachings. This is not true for throughfall leachate that usually represents

Table 5. Comparison of Volume and Chemistry of Mount Moosilauke Forest Floor Leacheate. ${ }^{*}$

\begin{tabular}{lcrrrrr}
\hline Lysimeter & Date & $\begin{array}{c}\text { Volume } \\
(\mathrm{ml})\end{array}$ & $\mathrm{pH}$ & $\mathrm{H}^{+}$ & $\begin{array}{c}\text { Concentration } \\
(\mu \mathrm{eq} / \mathrm{l}) \\
\text { lonic } \\
\text { Strength }\end{array}$ \\
\hline GBLy 1 & $\mathbf{8} / 31 / 76$ & 380 & 3.64 & 229 & 838 \\
GBLy 1 & $9 / 14 / 76$ & 1,100 & 3.87 & 135 & 313 \\
GBLy 1 & $8 / 11 / 76$ & 1,950 & 4.32 & 48 & 152 \\
GBLy 2 & $9 / 14 / 76$ & 1,200 & 4.17 & 68 & 268 \\
GBLy 2 & $6 / 09 / 76$ & 1,990 & 4.52 & 30 & 184 \\
\hline
\end{tabular}

* From Cronan, 1978, p. 72.

Grand average $\mathrm{H}^{+}=102 \times 10^{-6}=\mathrm{pH} 3.99$

Vol wt mean $\mathrm{H}^{+}=71 \times 10^{-6} \mathrm{eq} / \mathrm{l}=\mathrm{pH} 4.15$ 
substantial rain following a dry period and is therefore affected by varying salt content. Since most samples were not volume averaged to give mean concentrations (Cronan, 1978, p. 72), this effect is obscured. Analyses of five comparable samples collected from two lysimeters during the summer of 1976 (Cronan, 1978, p. 72) clearly demonstrate the salt and volume effect: as salt increases and volume decreases, $\mathrm{pH}$ decreases dramatically (Table 5). Also the difference between grand average $\mathrm{H}^{+}$concentration and volume weighted mean $\mathrm{H}^{+}$ concentration is about the same as the difference between $\mathrm{H}^{+}$concentrations of throughfall versus snowmelt. In Norway, Abrahamsen (1980) correctly noted the salt effect: low $\mathrm{pH}$ of leachate occurred after periods of drought and was associated with smaller volumes of water.

Cronan and Schofield (1979) also maintain that acid rain is dissolving $\mathrm{Al}$ from the $\mathrm{B}$ horizon, thus reversing the historical trend of accumulation of $\mathrm{Al}$ in podzol subsoils. They assume that all aluminum leached from the A horizon is normally immobilized in the B horizon. However, leaching of Al from soil and its subsequent appearance in surface waters was reported as early as 1930 by Joffe. He attributed the presence of aluminum in some rivers to soil-forming processes and urged further study because aluminum is a "toxic agent" and a "disturbing factor in connection with soil acidity." That the B horizon is not a perfect barrier against movement of aluminum has since been confirmed by a number of studies (Tamm, 1950, p. 144; Rode, 1955, p. 155; Petersen, 1976; and Krug, 1981).

In further support of the contention that acid rain is removing $\mathrm{Al}$ from the $\mathrm{B}$ horizon, Cronan and Schofield (1979) compare the high concentrations of aluminum in spring water near the New Hampshire site with a low concentration in spring water near the Washington site (Ugolini et al., 1977a). At the Washington site, one third to one half of the aluminum remained in solution in the $\mathrm{B}$ horizon. It does not appear in the nearby spring water because it precipitates as water moves through the fractured basic andesite bedrock (Ugolini et al., 1977a). In contrast, the Mount Moosilauke site is underlain by the Littleton Formation, an impervious and "acid" rock formation (Cronan, 1978, p. 25; and Johnson et al., 1968).

Cronan and Schofield (1979) further state that leachate at the New Hampshire site from the forest floor and the mineral $A_{2}$ horizon contains less aluminum than adjacent spring water. The difference is attributed to $\mathrm{Al}$ leached from the subsoil by acid rain. Examination of Cronan's data (1978, p. 73), however, indicates that the leachate is only that from the forest floor (Table 4) and does not include any leachate from mineral soil horizons. Organic matter contains relatively little $\mathrm{Al}$ that is extractable with acids; hence, it is not surprising that leachate from the forest floor is considerably more acid than spring water and yet has less aluminum. Also, volume and composition of leachate from each horizon need to be measured to determine the net flux of aluminum. This was not done at the Mount Moosilauke site. It is even possible that the quantity of aluminum exported
Table 6. Dissolved Aluminum and $\mathrm{pH}$ of $100 \mathrm{ml}$ of Dilute $\mathrm{H}_{2} \mathrm{SO}_{4}$ and Water After 24 Hours of Reaction with 20 g. of Hubbard Brook Soil*.

\begin{tabular}{|c|c|c|c|c|}
\hline \multirow[t]{2}{*}{$\begin{array}{l}\text { Sample } \\
\text { Horizon }\end{array}$} & \multicolumn{2}{|c|}{$\begin{array}{c}3.5 \times 10^{-5} \mathrm{~N} \mathrm{H}_{2} \mathrm{SO}_{4} \\
(\mathrm{pH}=4.45)\end{array}$} & \multicolumn{2}{|c|}{$\begin{array}{c}\text { Deionized } \mathrm{H}_{2} \mathrm{O} \\
(\mathrm{pH}=5.41)\end{array}$} \\
\hline & $\mathrm{pH}$ & Al & $\mathrm{pH}$ & $\mathrm{Al}$ \\
\hline $\mathrm{O}_{1}$ & 4.11 & 9.6 & 4.07 & 15.6 \\
\hline $\mathrm{O}_{2}$ & 3.81 & 4.4 & 3.79 & 4.1 \\
\hline$A_{2}$ & 4.58 & 4.1 & 4.71 & 2.6 \\
\hline $\mathrm{B}_{2 \mathrm{~h}}$ & 4.34 & 15.9 & 4.37 & 23.7 \\
\hline $\mathrm{B}_{\text {2ir }}$ & 4.51 & 14.8 & 4.50 & 21.1 \\
\hline $\mathrm{B}_{3}$ & 4.67 & 14.6 & 4.80 & 13.7 \\
\hline
\end{tabular}

* From Mülder, 1980, p. 20. [Al] reported as $\mu$ moles $/$.

in spring water may be less than from the forest floor because not all of the water reaches springs, some of it is lost from the mineral soil by evapotranspiration.

Finally, Cronan and Schofield (1979) apparently believe that all aluminum is normally combined with organic anions in acid soils. The presence of ionic aluminum in solution, particularly where $\mathrm{SO}_{4}=$ is the dominant anion, is therefore attributed to acid rain. While $\mathrm{SO}_{4}{ }^{2}$ can replace humate in leachate from acid soil receiving acid rain, this is not evidence that aluminum and cation leaching is enhanced. The presence of considerable $\mathrm{SO}_{4}{ }^{2}$ in runoff and leachate from many acid soils has been known since the early 1930's (Heimath, 1933; Joffe, 1933; Atkinson and McKibbin, 1934; Hutchinson, 1957, p. 682; and Gorham, 1958) when mineral acids rather than organic acids were thought by many to be the principal acidifying components of soil.

Not all aluminum in leachate from the forest floor is necessarily combined with organic acids. Humic acids have long been known to increase total concentrations of aluminum in solution, with Mattson and Hester (1933) being the first to show that the formation of organoaluminum complexes decreases the concentration of ionic aluminum in soil solution. In moderately acid podzols this may remove nearly all ionic aluminum from solution. In extremely acid podzols it removes only a fraction. This is because ionic aluminum (while depressed in concentration) becomes naturally more important, and organo-aluminum less important as soils become more acid (Boratyński and Mattson, 1939). The decreasing affinity of $\mathrm{Al}$ for humic acids with decreasing $\mathrm{pH}$ has been ivell established in the recent literature (Schnitzer and Hanson, 1970; Kerndoff and Schnitzer, 1980; and Hargrove and Thomas, 1981). Boratyński and Mattson (1939) also showed that the solubility of organoaluminum decreases with decreasing $\mathrm{pH}$, becoming especially significant at $\mathrm{pH} 4$ or less. This dependence of the solubility and mobility of humic acids on $\mathrm{pH}$ is also well documented in recent years (Hayes and Swift, 1978, p. 281; Ghosh and Schnitzer, 1980; and Ritchie 
and Posner, 1982). Therefore, the lower mobility of humic acids in the New Hampshire sites relative to the Washington sites is probably due to the naturally greater acidity of the New Hampshire soils. It could also be attributed in part to immobilization of humic acids by acid rain (McColl et al., 1982).

While it is popular to attribute all leaching phenomena in podzols to leaching of humic acids, van Schuylenborgh and Bruggenwert (1965) note that leaching of Al from the A horizon of podzols at about $\mathrm{pH} 4$ can be explained by the effects of $\mathrm{pH}$ on the solubility of $\mathrm{Al}$. lonic aluminum can then accumulate in the lower horizons by a variety of mechanisms, including immobilization by humic materials.

All constituents in acid rain must be considered in evaluating its effects on $\mathrm{Al}$ chemistry. Basic cations in rain may promote exchange of ionic aluminum from acid soil into leachate and runoff. Indeed, the snowmelt study of Seip et al. (1980) shows that for a period of several weeks, $\mathrm{Na}$ in neutralized snowpack replaced $\mathrm{Al}$ on exchange sites, increasing the concentration of $\mathrm{Al}$ in the runoff from neutralized snow to about twice that observed in the runoff from the snowpack with $\mathrm{pH} 4.3$. Acid rain may also increase the concentrations of basic cations in forest throughfall. Although these leached cations are apparently taken up again by the forest (Eaton et al., 1973), the effect of this on Al chemistry is unknown.

Future studies need to distinguish between ion exchange by neutral salts and dissolution of aluminum by acids. The usual criteria for determining the presence of a solid crystalline phase is the constancy of the apparent solubility product in soil solutions or soil extracts. Unfortunately, ion exchange can produce the same apparent constancy over a fairly wide range of salt concentrations and soil-to-solution ratios (Lindsay et al., 1959). Thus, $\mathrm{pH}-\mathrm{Al}$ relationships which appear to reflect the presence of a solid phase must be carefully examined (Frink, 1973). The effects of anions on ionic aluminum must also be considered. Burgess and Pember (I923) showed that large additions of acid phosphate more acid than soil actually reduced concentrations of ionic aluminum. Research in agricultural soils has also shown that sulfate may be retained in acid soils by reaction with amorphous or poorly crystalline hydrolysis products of iron and aluminum.

Joffe and McLean (1928a and b) studied the movement of various forms of $\mathrm{Al}$ in agricultural soils. Aluminum able to diffuse through semi-permeable membranes was defined as ionic. In soils at $\mathrm{pH} 5$ or above, most aluminum in soil solution was in colloidal or nondiffusible form. Ionic aluminum increased with decreasing soil $\mathrm{pH}$, and at $\mathrm{pH}\left(\mathrm{H}_{2} \mathrm{O}\right) 4.2$, most aluminum was ionic and hence soluble. They also showed that sulfate and other polyvalent anions decreased the concentrations of both ionic and colloidal Al in soil solutions. Later, Mattson and Hester (1933) added organic anions to the list of anions that can reduce concentrations of ionic Al in solution. More recently, Yuan and Hsu (1971) have shown that fluoride and various clay minerals, as well as sulfate, all enhance precipitation on the acid side of the optimum precipitation $\mathrm{pH}$ for the Al-OH- $\mathrm{PO}_{4}$ system. In summary, it seems possible that sulfate in acid rain may act in conjunction with other inorganic anions to limit the concentrations of ionic aluminum in solution.

The effects of adding $\mathrm{H}_{2} \mathrm{SO}_{4}$ to soil from Hubbard Brook are shown in Table 6. These results caused Mülder (1980) to wonder whether $\mathrm{H}_{2} \mathrm{SO}_{4}$ was increasing or decreasing leaching: the concentration of $\mathrm{Al}$ in solution from horizons normally having high concentrations was depressed by about one third by addition of $\mathrm{H}_{2} \mathrm{SO}_{4}$, while $\mathrm{Al}$ and acidity from the $\mathrm{A}_{2}$ and $\mathrm{B}_{3}$ horizons was increased slightly upon treatment with acid. Sulfate also seems to limit the concentration of $\mathrm{Al}$ in leachate from the forest floor at nearby Mount Moosilauke: the correlation coefficient between $\mathrm{H}^{+}$and $\mathrm{SO}_{4}=$ in the 10 samples reported (Cronan, 1978, p. 72) is $\mathrm{r}^{2}=0.88$. The concentration of sulfate in the leachate was about 2.6 times greater than $\mathrm{H}^{+}$on an equivalent basis, while in rain this proportion is about 0.9 (Cronan, 1978, pp. 72-73). Indeed, as Figure 7 illustrates, the concentration of $\mathrm{Al}$ in leachate decreases with increasing acidity.

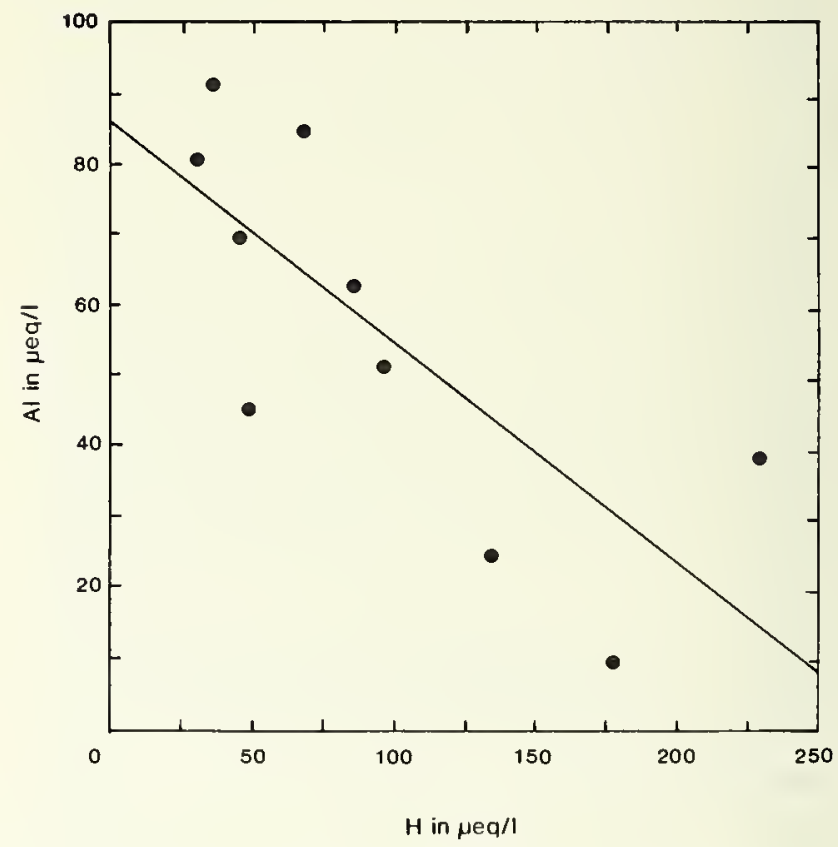

Figure 7. The correlation of $\mathrm{H}^{+}$and $\mathrm{Al}$ Concentration in Samples of Leachate from the Forest Floor at Mount Moosilauke.*

"From Cronan, 1978, p. 72. Al in $\mu$ eq/l assumes that $\mathrm{Al}$ is $\mathrm{Al}^{+3}$.

In conclusion, the interaction of acid rain with soil is more than simple dissolution of aluminum compounds by acid. Further studies are necessary to predict the impact that $\mathrm{H}^{+}, \mathrm{SO}_{4}=$, and basic cations in acid rain will have on organo-aluminum and other aluminum species in soil. 


\section{Changing Land Use}

Societal and technological evolution associated with demographic transition are underlying factors responsible for both acid rain and drastic changes in land use. Earlier, exploitation of forests was widespread and highly destructive. The remaining forests of western Europe all bear the influence of man (Stone, 1975). The extensive heaths of Great Britain, Scandinavia, and the borders of the North Sea are the consequence of earlier and careless land use (Bramryd, 1979). Several thousand years of burning, grazing, and lumbering caused severe erosion that helped to create the unusually thin soils and low tree line of the uplands and low mountains of southern Norway (Rosenquist, 1978 and 1980; Overrein et al., 1980 , p. 102). These careless practices were transported to eastern North America with the arrival of Europeans over three centuries ago (Defebaugh, 1906 and 1907).

Fortunately, the temperate forests of northern Europe and eastern North America are now recovering. Indeed forest recovery is so extensive in temperate climates that it is thought by some to be influencing the global carbon cycle (Bramyrd, 1979; Clawson, 1979; Armentano and Ralston, 1980).

The hypothesis that these changes in land use are largely responsible for acidification of soil and water in southern Norway was first advanced by Rosenqvist (1978 and 1980). There, land is reverting to acid heath and forest producing humus which becomes thicker and more acid with time. Rosenqvist (1980) documents the increase in forested land with statistics showing an increase of over $70 \%$ in the volume of standing wood in the southernmost counties of Norway during the period $1927 / 28$ to $1964 / 73$. The acidification potential of the accompanying humus is enormous: Rosenqvist (1978) estimates that the exchange acidity of the surface humus accumulated under a 90-year-old spruce forest on an abandoned Norwegian farm is equivalent to about 1000 years of acid rain of $1 \mathrm{~m} / \mathrm{yr}$ with $\mathrm{pH} 4.3$. Experiments showed that this humus acidified the equivalent of about 100 years of $\mathrm{pH} 8$ rain applied during three days, again demonstrating the enormous buffering and acidification potential of humus. He states that increasing amounts of increasingly acid humus and soil are acidifying runoff in watersheds where there is incomplete neutralization of acids by mineral weathering.

Forests are also recovering in other areas thought to be impacted by acid rain. The volume of wood in Swedish forests increased nearly $40 \%$ between $1927 / 1929$ and 1968/1972, with two-thirds of the net increase in standing wood occurring in southern Sweden alone (Bramryd, 1979). Fewer data are available for Canadian forests, but Armentano and Ralston (1980) estimate that present regrowth exceeds harvesting by about $100 \times 10^{6} \mathrm{~m}^{3} / \mathrm{yr}$. Likewise, in New England, the volume of wood has increased by about $70 \%$ between 1952 and 1976 , while the area of forest has been relatively constant (USDA, 1978).

Clearly, regions experiencing regional acid rain are undergoing dramatic regional changes in land use. Given the biological nature of soil acidification in humid temperate climates, it is clear that acid rain is not the only source of increasing acidity.

Land-use changes in southern New England and the coastal Northeast can be illustrated by Connecticut's history. Connecticut, like the rest of the Northeast, was essentially completely forested prior to the arrival of settlers. The role of the American Indian in burning the forests has apparently been overstated: descriptions of the pre-colonial forests by some 17th century commentators as being parklike and open may well have been propaganda designed to attract settlers (Russell, 1981). Those who did arrive treated the seemingly endless forest as an enemy and destroyed most of it by fire to clear the land (Fox, 1902; Moss, 1916; Harper, 1918; Dana, 1930; and Kingsley, 1974). By 1790, less than $40 \%$ of Connecticut was estimated to be forested (Harper, 1918; and Kingsley, 1974), and by 1820 , the virgin forests had virtually disappeared. About $25 \%$ of the area was then in second and later generations of thickets that were periodically cut. The scarcity of wood was one of the major causes of abandonment of mining in Connecticut. Wood remained in short supply in southern New England for some time because of slow replacement by coal as fuel (Moss, 1916; Harper, 1918; Lunt, 1948, p. 10; and Kingsley, 1974). The landscape of 1850 must have been particularly dreary in Connecticut where even the hillsides "have been rendered bleak by the removal of trees which formerly grew upon them" (Sec., Conn. Bd. of Agr., 1877, p. 199).

Since the mid-1800's, the acreage of forest in Connecticut has increased steadily. Census figures indicate that $21 \%$ of the state was wooded in 1860. A United States Geological Survey study found $38.5 \%$ to be wooded in 1889. Reforestation by planting of trees was encouraged in the 1870 's by financial incentives (Sec., Conn. Bd. of Agr., 1878, p. 70), which resulted in considerable planting of pine. By 1910, 50\% of Connecticut was wooded, exceeding the area estimated to be in forest in 1790 (Sec., Conn. Bd. of Agr., 1877, p. 199, 1901, pp. 262-266, 1914, pp. 63-68; and Harper, 1918). By 1952, $63 \%$ of Connecticut was forested, a figure that has dropped slowly to $58 \%$ in 1972 (Kingsley, 1974; and Dickson and Bowers, 1976). During these latter 20 years, the volume of wood increased by $61 \%$ per acre, with large sawtimber trees increasing $88 \%$ per acre (Dickson and Bowers, 1976).

Thus, essentially all of the forest in Connecticut has been disturbed repeatedly, with only a few acres untouched. The largest such area is located in Norfolk and is about five acres (Winer and Childs, 1956). At two locations, the forest is believed to have been only occasionally disturbed by man. One is the Cathedral Pines, an old field stand of about 20 acres of white pine now reverting to northern hardwoods (Hicock, 1956). The second site is Catlin Wood, a 15-acre stand of 150-170year-old northern hardwoods believed to be the only remaining reasonable representation of our pre-colonial forest (Smith, 1956). 
As the colonists moved inland, they continued to exploit the forests. By the 1770's, the Adirondacks were a region of continual lumbering, even serving the needs of Europe. By the early 1800's, lumbering was so intense that the rivers of the Adirondacks were regulated as public highways. White pine was the prize to be had then, but by 1850 most had been cut and other trees gained in commercial importance (Fox, 1902; and Defebaugh, 1907, pp. 387-404).

As demand increased, lumbering in the North woods intensified. In 1840, the first year with such data available, the Northeast accounted for $65 \%$ of the lumber produced in the United States (Dana, 1930, p. 8). In 1850, New York was the leading state in production of lumber (Ayres, 1909, p. 5). Such lumbering rates could not be sustained indefinitely. Lumbering in New York peaked sometime prior to 1865 , and then bottomed between 1880-1900, with the timber supplies of the Catskills and the Adirondacks having been virtually exhausted (Fox, 1902 , p. 5). Logging in other states in the Northeast followed a similar pattern (Fernow, 1902-03; Chittenden, 1905; and Harper, 1918) with little uncut forest remaining by 1900 .

Soon after the Civil War it became apparent that logging and fire had considerably damaged the Catskills and the Adirondacks. Defebaugh (1907, pp. 396-397) noted that not only was their usefulness as recreation threatened, but also waterflow was severely affected. In 1872, efforts were begun to preserve lands north of the Mohawk River, and eventually the Adirondack Park and Forest Preserve was established.

Following logging and farming in New England, land began to be abandoned because of ready access to the "new lands" to the west (Kingsley, 1974). The amount of cleared land in New England reached a peak about 1870 (Lunt, 1948). With the exception of Maine, much of New England was farmed (Dodge, 1891). Even in mountainous New Hampshire, only $37 \%$ was not farmed, but the flight to the west soon caused abandonment (Ayres, 1909). Some abandoned land reverted to stands of white pine (Ayres, 1902-03; and Chittenden, 1905) and even supported a modest resurgence of the white pine industry from 1900-1920 (Kingsley, 1974, p. 3).

The net result of fire, lumbering, and farming, however, was the conversion of most of the original mixed hardwood and coniferous forest into today's nearly pure hardwood forest of the lower slopes and valleys of the Adirondacks (Fox, 1902; Knechtel, 1902-1903; Bryant, 1917; and McCarthy, 1919), the White Mountains (Chittenden, 1905; and Bormann et al., 1970), and other areas throughout New England (Westveld et al., 1956). In northern New Hampshire and Vermont alone, it has been estimated that 1 to 2 million acres of spruce-fir forest have been converted to hardwood or northern hardwood forest (Lull, 1959; and Hart, 1964).

Following the decline in cutting of lumber and firewood in the Northeast, technology gave forestry in the Northeast a new industry--paper. Large areas of virgin spruce and fir forests existed in the Adirondacks and northern New England. While not especially desired for lumber, spruce (and later fir) were ideally suited for the paper-pulping technology of the time. Because these forests lay close to the major American markets for paper, they were heavily exploited. We shall show that the demand for pulpwood caused dramatic changes in land use in precisely those landscapes where such changes have the greatest impact on runoff, the thin and organicrich soils of the slopes.

Production of pulp began about 1870-1875, and by 1890-1895 cutting of spruce began in earnest (Murphy, 1917 , p. 2). From $1890-1905$, cutting of pulpwood in the Adirondacks increased nearly six-fold (Defebaugh, 1907, p. 405). Similar increases occurred in New Hampshire and Maine (Chittenden, 1905, p. 83).

Initially, when demand was not great, individual spruce trees were culled from the more accessible mixed forest of the valleys and lower slopes. As demand later increased, the nearly pure stands of spruce and fir on the steep slopes were clear cut. The hazards of erosion caused by clear-cutting watersheds were pointed out by Hawley and Hawes (1912, p. 217), who concluded, however, that clear-cutting was the most logical and economical method of harvesting the wood. For a change, the most widespread method of cutting also became the recommended practice (Ayres, 1902-1903; Cary, 19021903; Chittenden, 1905, p. 78; Bradley, 1908; Hawley and Hawes, 1912, pp. 209-220; Bryant, 1917; Belyea, 1922; Marshall, 1925; and Westveld, 1931, p. 6).

Concern about the extent of lumbering in the White Mountains caused the New Hampshire legislature to order a study of the region by Chittenden (1905). His report and land-use map are unique, being the only study of its kind that can be found in the Northeast. Chittenden surveyed about 2,000,000 acres in the northernmost part of New Hampshire, the only area still containing any major areas of virgin timber. He found that only about 200,000 acres of timber was uncut in 1903. Almost all the virgin timber was spruce-slope forest; essentially all of the hardwoods had been lumbered. Although the survey excluded the agricultural land along the Connecticut River, there was actually more farmland $(244,000$ acres $)$ in 1903 in the White Mountains than virgin forest. His land-use map also shows railway spurs coming from the south along the valleys (Chittenden, 1905), presumably to reach the last good stands of spruce. The rush to cut the remaining spruce is documented by Ayres (1909) and Very (1912).

From 1904 through 1923, the Northeast produced $56 \%$ of the nation's pulpwood, with $22 \%$ coming from New York alone (Kingsley, 1971). By 1927, Maine had become the lead state, with New York, Pennsylvania and New Hampshire in third, fifth and sixth places, respectively (Dana, 1930, p. 9). By this time, lumber interests became concerned that supply could not continue to meet demand in the Northeast. Virgin timber was nearly gone and second-growth wood was increasingly cut and processed. Conservation and silvicultural management was urged by the United States Forest Service (Meyer, 1929; Dana, 1930; and Westveld, 1931). The South gained pre-eminence in pulp production with 
development of a method for pulping of southern softwoods in the 1930's. Demand on spruce and fir in the Northeast further decreased with the pulping of hardwoods: by 1969, about half of the wood harvested for pulp in the Northeast was hardwood (Kingsley, 1971).

By 1940, Brown (in Bormann and Likens, 1979, p. 209) stated that few virgin forests remained in northern New Hampshire. This assessment is well illustrated by Oosting and Billings (1951) who compared virgin sprucefir forests of the southern Appalachians with those in the White Mountains in the northem Applachians. Although less than $10 \%$ of the original southern spruce forests were left in the 1930's (Korstian, 1937), Oosting and Billings easily selected nine virgin stands large enough for quantitative species analysis. However, in the White Mountains, even with the help of the United States Forest Service, they located only four stands-one of which was being cut as the study was in progress. Oosting and Reed (1944) also reported that there are few, if any, relics of the original coniferous forest in Maine.

A fraction of the spruce-fir forests in the Adirondacks was saved from clear-cutting by early action in New York to conserve the 7 million-acre region. By 1905, 1.3 million acres were owned by the State and protected from further cutting (Defebaugh, 1907, pp. 397-406). Today, the Adirondack Park covers 6 million acres with 2.3 million owned by the State (Dwyer, 1976). Less than 100,000 acres of all state-owned land in New York are believed to be virgin timber. It was estimated that 99.5\% of forests in New York had been lumbered or farmed by the 1920's (Marshall, 1925).

In conclusion, the net result of the paper-pulping industry was that the spruce-fir forests of the Northeast were heavily cut during the late 19 th and early 20 th centuries. These forests cover Adirondack and northern Appalachian slopes from elevations of about 2,500 to 4,900 or more feet. Further north, the altitudinal gradient decreases to about 2,000 feet in the Canadian Laurentians and as low as sea level in Maine. Going south, the altitude range of these forests increases, reaching 4,500 to 6,500 feet or more in the Great Smoky Mountains (Heimburger, 1934; Diebold, 1941; Oosting and Billings, 1951; Westveld, 1953; Whittaker, 1956; and Mclntosh and Hurley, 1964).

\section{The Effects of Changing Land Use}

Changes in land use were so dramatic in Connecticut that Station scientists began studies of the effects of red pine planted on abandoned corn and tobacco fields around 1900. By 1929, an organic surface horizon had developed with a $\mathrm{pH}\left(\mathrm{H}_{2} \mathrm{O}\right)$ of about 4.4. By 1944, the forest floor had thickened, and its $\mathrm{pH}\left(\mathrm{H}_{2} \mathrm{O}\right)$ had dropped to about 3.8 (Lunt, 1951).

Other plots were established in 1926 and 1927 in Connecticut's young hardwood forests to study changes in forest and soil over time (Hicock et al., 1931). While protected from cutting and burning, these forest plots have suffered various degrees of mortality from disease, drought and defoliation. Consequently, the forest at specific sites is now older, of approximately the same age (moderate dieback), or younger (severe dieback) than when established over 50 years ago (Table 7). Where the forest is older, mull humus has changed to acid mor humus. Where the forest is approximately the same age, the soil is little changed. Where the forest has died back recently, the acid mor humus is largely replaced by a less acid $\left(\mathrm{O}_{1}\right)$ organic horizon (Table 7$)$. If Connecticut's forests are allowed to mature in age and species composition as in Catlin Wood, we might expect the weight of the forest floor to increase and become more acid. At well-drained sites in Catlin Wood, the forest floor is 5 to $10 \mathrm{~cm}$ thick and the humus $\mathrm{pH}\left(\mathrm{H}_{2} \mathrm{O}\right)$ is 3.6 to 3.8 . The increase in weight, thickness and acidity under such hardwood forests in the humid temperate zone is well documented (Salisbury, 1922; Cain and Friesner, 1929; Griffith et al., 1930; Morgan, 1931; Lunt, 1932 and I948; Hough, 1943; Lull, 1959; Hart, 1961; Mader et al., 1977; Bormann and Likens, 1979; and Covington, 1981). The decrease in $\mathrm{pH}$ is particularly pronounced in agricultural soils as they become reforested by hardwoods as shown in New England (Griffith et al., 1930; Lunt, 1932 and 1948), New Jersey (Hanks, 1971), and England (Jenkinson, 1971).

Humus developed under coniferous and ericaceous vegetation in areas said to be sensitive to acid rain is particularly thick, acid, and low in nutrients in comparison to that under other vegetation. The differences in acidity are generally reflected in the mineral $\mathrm{A}$ and $\mathrm{B}$ horizons as well (Griffith et al., 1930; Lunt, 1932; Potapov, 1933; Young, 1934; Chandler, 1939; Donahue, 1940; Hough, 1943; Nihlgard, 1971; Bergseth, 1977; and Mollitor and Raynal, 1982). Under such vegetation, the humus continues to become thicker, more acid and poorer in nutrients with time, sometimes to the point where forest production and growth suffer greatly.

Plice (1934) showed that the $\mathrm{pH}$ and thickness of forest floors of mixed hardwood-conifer stands in the Northeast are intermediate between pure hardwood and coniferous stands, although the forest floor tends to more closely resemble that of the coniferous forest. His observations are well supported by data on Adirondack forest soils (Young, 1934; Chandler, 1939; Donahue, 1940; Diebold, 1941; and Eaton and Chandler, 1942), New England forest soils (Lunt, 1932 and 1948) and by studies in the Allegheny National Forest in Pennsylvania on the same soil types and parent materials (Hough, 1943).

An important task of the northern European forester - and particularly the Scandinavian-is to prevent forest dieback caused by excessive accumulation of mor humus under aging coniferous forests and to prevent reversion of productive hardwood forest to less productive conifers. For example, the 80,000 sample soil survey of Sweden shows that coniferous forests older than 100 
Table 7. Hardwood Forest Plots in Connecticut, 1927-1981.

\begin{tabular}{|c|c|c|c|c|c|}
\hline \multicolumn{6}{|c|}{ Aged Forest } \\
\hline & 1927 & & & 1981 & \\
\hline Horizon & Depth $(\mathrm{cm})$ & $\mathrm{pH}_{\mathrm{H}_{2} \mathrm{O}}$ & Horizon & Depth $(\mathbf{c m})$ & $\mathrm{pH}_{\mathrm{H}_{2} \mathrm{O}}$ \\
\hline$O_{1}$ & 0.6 & 5.46 & $O_{1}$ & 0.6 & 3.95 \\
\hline $\begin{array}{c}\text { A } \\
\text { (mull humus) }\end{array}$ & 2.5 & 5.55 & $\begin{array}{c}\mathrm{O}_{2} \\
\text { (mor humus) }\end{array}$ & 2.5 & 3.90 \\
\hline$B_{h}$ & 9.5 & 5.10 & $B_{h}$ & 10.0 & 4.64 \\
\hline
\end{tabular}

1927

Mixed Dieback

\begin{tabular}{cccccc} 
& 1927 & & & 1981 & \\
Horizon & Depth $(\mathrm{cm})$ & $\mathrm{pH}_{\mathrm{H}_{2} \mathrm{O}}$ & Horizon & Depth (cm) & $\mathrm{pH}_{\mathrm{H}_{2} \mathrm{O}}$ \\
$\mathrm{O}_{1}$ & 0.6 & 3.91 & $\mathrm{O}_{1}$ & 0.6 & 4.56 \\
$\mathrm{O}_{2}$ & 2.5 & 3.61 & $\mathrm{O}_{2}$ & 2.5 & 3.75 \\
$\mathrm{~B}_{\mathrm{h}}$ & 7.0 & 4.20 & $\mathrm{~B}_{\mathrm{h}}$ & 7.0 & 4.18 \\
\hline
\end{tabular}

Recent Severe Dieback

1927

\begin{tabular}{cccccc} 
Horizon & Depth $(\mathrm{cm})$ & $\mathrm{pH}_{\mathrm{H}_{2} \mathrm{O}}$ & Horizon & Depth $(\mathrm{cm})$ & $\mathrm{pH}_{\mathrm{H}_{2} \mathrm{O}}$ \\
$\mathrm{O}_{1}$ & 1.3 & 4.17 & $\mathrm{O}_{1}$ & 3.2 & 4.17 \\
$\mathrm{O}_{2}$ & 3.8 & 3.84 & $\mathrm{O}_{2}+\mathrm{A}_{1}$ & 1.4 & 3.86 \\
$\mathrm{~B}_{\mathrm{h}}$ & 13.0 & 4.32 & $\mathrm{~B}_{\mathrm{h}}$ & 2.5 & 4.25 \\
\hline
\end{tabular}

years have been thinned and the $\mathrm{pH}$ of the humus is slightly higher than that of 80 to 100 year-old forests not thinned (Troedsson, 1980). A variety of techniques have been developed to prevent buildup and acidification of humus, including selective-cutting or thinning, clearcutting, planting hardwoods in coniferous forests, and replanting with the desired species after treatment of the forest floor. The more extreme the treatment (e.g., clear-cutting versus selective-cutting, more intensive burning), the greater the reduction of acidity and depth of humus and forest floor. Often, combinations of these techniques are used with results discussed by Lutz and Chandler (1946, pp. 183-188); (Tamm, 1950; Marbut, 1951, pp. 87-88; Ahlgren and Ahlgren, 1960; and Viro, 1974). Studies of various lowland Adirondack forest types show that, 20 to 50 years after cutting and burning, depth of humus is substantially reduced and the $\mathrm{pH}$ of the humus is generally about 1 unit higher when compared with relatively undisturbed sites (Young, 1934). Clearly, this cycle of growth, cutting and burning, and subsequent regrowth has had measurable and substantial effects on soil acidity.

As noted earlier, much of the original mixed hardwood-coniferous forests of the lowlands and foothills of the Northeast have been replaced by essentially pure stands of hardwoods as a consequence of disturbance. As these stands mature, we expect that forest floors will thicken and become more acid with time, but will not become as thick and acid as the forest floor under the original forest. Thus, maturing forests of lowlands and foothills of the Northeast are not expected to cause sig- nificant widespread acidification of water. Soils in these areas are generally deep and have enormous acidneutralizing capacity. Contact time of runoff with soil is generally sufficient to neutralize acidity exported from the upper horizons.

Acidification of water may occur where runoff does not have an opportunity to thoroughly react with and thereby be neutralized by subsoil and deeply permeable geologic materials. Examples can be found in the intermittent headwater streams in Hubbard Brook and similar locations. Others are found with ponds and streams in peaty wetlands as exemplified by a pond in the Arboretum at Connecticut College in New London, or Miry Brook at Catlin Wood. Also, such sites have restricted rooting caused by relatively shallow depths of soil to bedrock or water table and tend to be more coniferous than adjacent sites. Additionally, streams running through beds of sphagnum moss, as at Emmons Pond in Connecticut, may be acidified in part by biological ion exchange.

Another exception would be areas where deep humus podzols have developed on highly permeable materials poor in aluminosilicate minerals, such as the New Jersey Pine Barrens (Krug, 1981). Acidity from increasingly acid surface horizons may be transmitted into surface and ground waters. In the Pine Barrens, where this process has not been interrupted by glaciation, a unique flora and fauna have had time to develop and adapt to the extremely acid water (Patrick et al., 1979; and Patrick et al., 1981).

However, soils developed under productive forests of 
the upper slopes, and thin and rocky soils in general, naturally have extremely thick and acid humus-thicker and more acid than those of the lower slopes and valleys. Similar land-use changes will result in greater increases in depth and acidity under recovering upland forests relative to the more lowland forests.

The relationship between soil acidity and vegetation had attracted considerable attention by the 1920 's, attested to by a review article with 750 citations, of which more than 500 dealt directly with acidification (Wherry, 1928). It is not surprising that Salisbury (1922) concluded 60 years ago that forest recovery was causing widespread acidification of soils in Great Britain. He further concluded that changing land use caused greater acidification of landscapes at higher elevations because soil formation is naturally more acid there than on the lower slopes and valleys. Given that neutralization of acids by mineral weathering may not be complete in many thin and rocky soils, especially those on steep slopes, there can be little doubt that increasing amounts of increasingly acid humus and soil can acidify water as well.

In the Northeast, the most extreme changes in land use occurred as a result of clear-cutting of the spruce and fir forests on the upper slopes. Clearly, such lumbering of these slope forests was more destructive than at lowland sites. Another extremely severe consequence of lumbering the slope forests was fire. Although forest fires are a major factor in most forest ecosystems, early literature indicates that fires were rare in the spruce and fir forests of eastern North America. Lumbering, however, was almost invariably followed by fire with the thick humus layer being largely or completely destroyed (Knechtel, 1903-1904; Chittenden, 1905; Ayres, 1909; Bryant, 1917; Belyea, 1922; MacDonald, 1925; Korstian, 1937; Minckler, 1945; and Lutz and Chandler, 1946, p. 183).

During clear-cutting, the logs were removed after slashing-off tops and branches. After drying, this resinous slash burns readily. Likewise, the now unshaded forest floor dries quickly and will also burn. Steep slopes provide updraft, and the resulting fires are particularly severe. Knechtel (1903-1904) described the scene in the Adirondacks in 1903 when about 300,000 acres burned that summer, producing sufficient smoke so that "at night the stars were obscured and the moon was dull and red above the smoky and smoking horizon."

Fires induced by man were an acute problem in the Adirondacks soon after the Civil War and were in part responsible for the creation of the State Park Commission (Defebaugh, 1907, pp. 396-397). Between 1891 and 1920, nearly 1.3 million acres were burned (Diebold, 1941). The result was a considerable increase in interest in the effects of fire on hydrology and soil erosion. A particular concern was the effect of fire on depth of the forest floor. Fires in spruce-fir forests seem to have the greatest effect on depth of forest floor of any Adirondack forest type, being reduced from an average thickness of 14 inches for virgin forests to an average of 2 inches when measured 20 to 30 years after burning. Likewise, thick forest floors are found under similar virgin slope forest types in the White Mountains and Laurentians (Heimburger, 1934; and Oosting and Billings, 1951).

According to Hoyle (1965), the depth of forest floor on the steeper slopes of the White Mountains ranges from discontinuous to several inches, indicating widespread destruction of the original forest floor. Such reductions in depth may also occur in the absence of fire. In cut-over, but unburned Adirondack spruce forests, Kittredge and Belyea (1923) observed that the humus was typically 1-3 inches deep over loamy and usually shallow soils with frequent outcrops of rock.

Presently, the White and Green Mountain regions of northern New England have an exceptionally low susceptibility to forest fire (Bormann and Likens, 1979, pp. 201-212). This, combined with efficient fire control, accounts for the fact that only 8 out of $1,000,000$ acres on the average burns annually in the White Mountain National Forest. Fahey and Reiners (1981) have recently shown that the spruce-fir forests are the least susceptible to fire of any forests in northern New England, with a mean fire rotation time measured in thousands of years. The longest rotation times in other North American forests are about 500 years for the forests in the extremely moist climates of the northern Rockies and Pacific Coast.

Another consequence of exploitation was vast and destructive outbreaks of insects and diseases (Hopkins, 1899; Korstian, 1937; Spaulding and Hansbrough, 1944; Westveld, 1953; Eschner and Satterlund, 1966; Ferguson and Kingsley, 1972; and Frank and Bjorkbom, 1973).

Between clear-cutting, fire, and attack by insects and disease, the forests occupying landscapes believed to be especially vulnerable to acid rain were widely devastated around the turn of the century.

Today, the forests are recovering (USDA, 1978). Maine contains about $80 \%$ of the spruce and fir in New England (Hart, 1964). Between 1959 and 1971, the amount of wood in spruce and fir increased two to three times as much as the average for all other wood types in Maine, although spruce and fir are the mainstay of the large paper industry in the state (Ferguson and Kingsley, 1972). The increase is attributed in large part to recovery from budworm attacks and fires, since the area of spruce-fir forest has remained relatively constant (Ferguson and Kingsley, 1972, p. 11). In New Hampshire, the area of spruce-fir forests nearly doubled between 1949 and 1960 , reaching a total of 1.1 million acres (Ferguson and Jensen, 1963). In Vermont, the acreage increased $18 \%$ in seven years, to a total of nearly 0.8 million acres in 1973 (Kingsley, 1977).

There seems little doubt that changes in land use of the magnitude reported here can contribute significantly to acidification of lakes and streams. High altitude waters of the Adirondacks have become somewhat more acid between the 1930's and the 1970's. The great acidification reported earlier (Schofield, 1976a and b) is apparently largely due to differences in measurement of $\mathrm{pH}$, and the reported fish declines are due in part to discontinuation of stocking (Pfeiffer and Festa, 1980). However, acid rain was not reported to occur in upstate New 
York until the 1950's (Likens and Bormann, 1974). Recently, a parallel has been drawn between acid rain and Theodore Dreiser's novel "An American Tragedy." As a man, motivated by greed, drowned a woman in Big Moose Lake in the Adirondacks, so today society is accused of killing Big Moose Lake with acid rain (Blumenthal, 1981; and Boyle, 1981). By local accounts, however, Big Moose Lake began dying in the 1930's (Blumenthal, 1981).

While the report of the first four years of the SNSFproject considered acid rain to be the sole source of acidification of lakes and streams in Norway (Abrahamsen et al., 1976; Gjessing et al., 1976; and Leivestad et al., 1976), the final report acknowledges that changes in land use have long been known to acidify soil and that these changes in general affect the alkalinity and $\mathrm{pH}$ of rivers and lakes (Overrein et al., 1980). The report further notes that "agriculture and silviculture in Norway have undergone dramatic changes during the last 100-150 years" (Overrein et al., 1980, p. 92). However, the report considers changes in land use to be a minor factor and concludes that the observed increases in sulfate in runoff and the presumed equivalent increases in leaching of hydrogen, aluminum and other cations are responsible for the most substantial portion of the observed increases in acidity and mortality of fish (Overrein et al., 1980). However, acidification of mountain lakes in southern Norway apparently began around 1900 (Rosenqvist, 1978 and 1980; and Overrein et al., 1980). Where losses of salmon fisheries have been reported in rivers in southern Norway, most of the decline is reported to have occurred between 1910 and 1920 , with massive fish kills being observed as early as 1911 after heavy rains and rapid snowmelts. Acidification of fresh waters in southern Norway created growing public concern by the 1920's (Leivestad et al., 1976). Acid rain, however, was first observed in southernmost Norway around 1950, with a large increase in the area and acidity of rain occurring in the mid-1960's (Egner and Ericksson, 1955; Dovland et al., 1976; Cogbill, 1976; Likens, 1976; and Overrein et al., 1980).

The recent Proceedings of the Acid Precipitation Research Needs Conference in New York (N.Y.D.E.C., 1982 , p. 19) also recognizes the possible acidification by changing land use: "Acidification of Adirondack Lakes may be related to long-term natural trends accelerated by acid rain. There is a need to quantify and differentiate between these two acidification processes. . . " Again, it is proposed that the effects of acid rain can be quantified by measuring leaching of sulfate (N.Y.D.E.C., 1982).

The role of changing land use was dismissed in one paragraph in a recent report of the National Academy of Sciences (National Research Council, 1981, p. 147):

"The theory that the acidification observed in poorly buffered fresh waters was due to changing land-use patterns (Rosenqvist, $1978 \mathrm{a}, \mathrm{b})$ has now been discounted as an explanation for the widespread effects observed, particularly in remote areas. Detailed study over several years of watersheds in Norway, some with changing land-use patterns and some without, has shown that, on the average, both are acidified at equal rates (Drabløs and Sevaldrud, 1980; Drabløs et al., 1980). Moreover, studies of lakes in North America in areas where land-use patterns have never changed have also shown substantial increases in hydrogen ion or losses in buffering capacity (Dillon et al., 1978; Watt et al., 1979)."

Careful examination of the four studies said to disprove the land-use hypothesis reveals that substantial changes in land use have occurred in three of the four areas studied. The fourth was a lake with an unusually small ratio of drainage area to lake area that we discussed earlier as an example of the acidification by direct rainfall on the lake (Dillon et al., 1978).

One of the studies cited shows that a series of lakes and ponds in Nova Scotia are more acid than when examined 21 years earlier in 1955 (Gorham, 1957; and Watt et al., 1979). Surprisingly, near neutral waters with the greatest buffering capacity suffered greatest acidification. Because the watersheds had been largely undisturbed between studies, acidification was attributed to acid rain (Watt et al., 1979). However, what is important is what happened prior to 1955 . Woodward (1906) notes that this area of Nova Scotia was treeless and barren as the result of widespread and very destructive fires set by gold miners to remove both the forest and forest floor in order to locate gold-bearing rock. This history was acknowledged by Gorham (1957), who noted that probably all of the watersheds have been subjected to repeated burning and cutting and that differences in lake chemistry at the time were probably associated with differences in soils and vegetation. Gorham (1957) further described these waters as located in heathy spruce forest, with peaty soils and floating bog mats around the edges of many of the lakes.

We propose that the more recent acidification can be attributed largely to differences in soil formation as reflected by differences in types of bedrock. Lakes in granitic watersheds were quite acid by 1955: one lake had a $\mathrm{pH}$ of 3.95 (Gorham, 1957), indicating that acidification of soil in granitic watersheds was already quite advanced. In the remaining watersheds, the bedrock is more basic as indicated by the greater alkalinity of the lakes. In these watersheds, chemical weathering rates are higher and soil acidification is slower. The land-use argument explains the otherwise puzzling observation that waters of greatest alkalinity underwent greatest acidification after 1955 (Watt et al., 1979).

The second case cited dealing with changes in land use involves two studies in southern Norway where changes in grazing were inferred from changes in numbers of livestock. In the first study (Rosenqvist, 1978 and 1980), a large net decline in livestock in a county in southernmost Norway was used to illustrate changes in land use. However, data from adjacent counties showed continued acidification but little net change in numbers of livestock, leading to the conclusion that land use is not a factor in acidification (Drabløs and Sevaldrud, 1980; Drabløs et al., 1980). This latter SNSF study is amplified upon in the Final Report of the SNSF-project (Overrein et al., 1980, pp. 91-104), which notes that locally, changes in grazing vary considerably and that more detailed studies are required to relate changes in grazing to 
acidification of lakes. The final report also indicates that forestry has undergone "dramatic change," and we note that these changes were not dealt with in the SNSF study.

The third case cited was several hundred miles to the northeast in Norway where there were substantial regional changes in grazing. However, local detailed surveys showed acidification restricted primarily to small lakes and ponds at or above local tree lines. Because little change in land use is reported to have occurred in this particular zone, acidification was attributed to acid rain. However, acidification was observed as early as 1950 (Drabløs and Sevaldrud, 1980; Drabløs et al., I980; Overrein et al., 1980, pp. 91-104), while monitoring stations show that acid rain did not reach the area until the 1960's (Egner and Eriksson, 1955; Dovland et al., 1976; and Overrein et al., 1980, p. 28).

Clearly, the case presented by the National Research Council (1981, p. 147) for dismissing the changing landuse hypothesis proposed by Rosenqvist is not particularly strong.

To summarize the land-use issue for the Northeast, the Adirondacks and other mountainous areas of the Northeast are not pristine environments upon which only acid rain is acting. Nearly the entire region has undergone extreme changes in land use with the areas that were ruthlessly cut and burned, reverting to a more natural state. Thus, the landscapes asserted to be impacted by acid rain are precisely those that are undergoing the greatest soil acidification following disturbance. These natural processes are precisely those attributed to acid rain: acidification, dissolution of aluminum, and depletion of nutrients. Because sulfuric acid in acid rain is not proportionally increasing leaching of cations from acid soils, it is clear that neutralization of acid rain is not restricted simply to mineral weathering. We believe that there is now sufficient evidence to indicate that increased leaching of sulfate can be countered by decreased leaching of humate. Buffering of soils and watersheds by humic acids is probably increasing as a consequence of changing land use. Accordingly, the interactions between acid rain, acid soil and land use cannot be ignored and need to be carefully examined on a watershed-by-watershed basis. 


\section{PART III. BIBLIOGRAPHY}

Abrahamsen, G. 1980. Effects of acid precipitation on soil and forest 4. Leaching of plant nutrients, p. 196. IN D. Drabløs and A. Tollan [ed.] Ecological Impact of Acid Precipitation. SNSF-project, 0slo. 383 pages.

Abrahamsen, G., K. Bjor, R. Horntvedt, and B. Tveite. 1976. Effects of acid precipitation on coniferous forest, pp. 37-63. IN F.H. Braekke [ed.] Impact of Acid Precipitation on Forest and Freshwater Ecosystems in Norway. FR6/76, SNSF-project, 0s10. 111 pages.

Abrahamsen, G., A. Stuanes, and K. Bjor. 1978. Interaction between simulated rain and barren rock surface. Water, Air, and Soil Poll. $11: 191-200$.

Abrahamsen, G. and A.0. Stuanes. 1980. Effects of simulated rain on the effluent from lysimeters with acid, shallow soil, rich in organic matter, pp. 152-153. IN D. Drablors and A. Tollan [ed.] Ecological Impact of Acid Precipitation. SNSF-Project, 0slo. 383 pages.

Adaris, P.W. and J.R. Boyle. 1982. The quantity and quality of nutrient cations in some Michigan spodosols. Soil Sci. 133:383-389.

Adamson, A.W. 1973. A Textbook of Physical Chemistry. Academic Press. 1079 pages.

Ahlgren, I.F. and C.E. Ahlgren. 1960. Ecological effects of forest fires. Bot. Rev. 26:483-533.

Almer, B., W. Dickson, C. Ekström, and E. Hörnström. 1978. Sulfur pollution and the aquatic ecosystem, pp. 271-311. IN J.0 Nriaga [ed.] Sulfur in the Environment. Part II: Ecological Impacts. WileyInterscience. 482 pages.

Andersson, F., T. Fagerström, and S.I. Ni1sson. 1980. Forest ecosystem responses to acid deposition - Hydrogen ion budget and nitrogen/tree growth model approaches, pp. 319-334. IN T.C. Hutchinson and M. Havas [ed.] Effects of Acid Precipitation on Terrestrial Ecosystems. Plenum Press. 654 pages.

Armentano, T.V. and C.W. Ralston. 1980. The role of temperate zone forests in the global carbon cycle. Can. J. For. Res. 10:53-60.

Atkinson, H.J. and R.R. Mckibbin. 1934. Chemical studies on Appalachian upland podsol soils. Can. J. Res. 11:759-769. 
Ayres, P.W. 1902-03. Forest problems in New Hampshire. J. Forestry $1: 121-125$.

Ayres, P.W. 1909. Commercial importance of the White Mountain Forests. USDA For. Serv. Circ. 168. 32 pages.

Bache, B.W. 1980. The acidification of soils, pp. 183-202. IN T.C. Hutchinson and M. Havas [ed.] Effects of Acid Precipitation on Terrestrial Ecosystems. Plenum Press. 654 pages.

Baldwin, H.I. 1977. The induced timberline of Mount Monadnock, N.H. Bu17. Torrey Bot. Clut 104:324-333.

Belyea, H.C. 1922. A suggestion for forest regions and forest types as a basis of management in Ner' York State. J. Forestry 20:854-868.

Bergseth, H. 1977. Relationen zwischen aciditat und vegetationstyp norwegischer valdboden. Acta Agr. Scând. 27:269-279.

Birkeland, P.V'. 1974. Pedology, Weathering, and Geomorphological Research. Oxford University Press. 285 pages.

Blumentha1, $R$. June 8, 1981. Acid rain in Adirondacks disrupts the chain of 1 ife. The Nel York Times, pp. BT and B14.

Bohn, H.L. 197E. Estimate of organic carhon in world soils. Soil Sci. Soc. Amer. J. 40:468-470.

Boratyński, K. and S. Mattson. 1939. The electro-chemistry of soil formation: III. The humate complex. Kungl. Lantbruks. Annal. 7:63-119.

Bormann, F.H. and G.E. Likens. 1979. Pattern and Process in a Forested Ecosystem. Springer-Verlag. 253 pages.

Bormann, F.H., T.G. Siccama, G.E. Likens, ard R.H. Whittaker. 1970. The Hubbard Brook ecosystem study: Composition and dynamics of the tree stratum. Ecol. Monogr. 40:373-388.

Bower, C.A. and E. Truog. 1940. Base exchange capacity determination as influenced by nature of cation employed and formation of basic exchange sâlts. Soil Sci. Soc. Amer. Proc. 5:86-89.

Boyle, R.H. September 21, 1981. An American Tradegy. Sports I1lustrated. pp. 68-82.

Bradley, R.R. 1908. Suggestions for the handling of pulpwood 1 ands in eastern Canada. J. Forestry 6:220-228.

Brady, N.C. 1974. The Nature and Properties of Soils, 8th ed. Macmillan Publishing Co. 639 pages.

Braekke, F.H. 1981. Hydrochemistry in 10\%-pH-soils of South Norway. 1. Peat and soil vater quaiity. Medd. Norsk. Inst. Skogforskning 36(No. 11). 32 pages. 
Bramryd, T. 1979. The effects of man on the biogeochenical cycle of carbon in terrestrial ecosystems, pp. 183-218. IN B. Bolin, E.T. Degens, S. Kempe, and P. Ketner [ed.] SCOPE 13: The Global Carbon Cycle. John Wiley \& Sons. 491 pages.

Bridge, J.E. and F.P. Fairchild. 1981. Northeast Danage Report of the Long Range Transport and Deposition of Air Pollutants. Northeast Regional Task Force on Atmospheric Deposition. 72 pages.

Brown, I.C. and H.G. Byers. 1938. Chemical and physical properties of certain soils developed from granitic materials in Nel! England and the Piedmont, and of their colloids. USDA Tech. Bul1. 609. 56 pages.

Bryant, R.C. 1917. Silviculture at Axton and in the Adirondacks generally. J. Forestry 15:891-895.

Burgess, P.S. and F.R. Pember. 1923. "Active" aluminumi as a factor detrimental to crop production in many acid soils. RI Agr. Exp. Sta. Bul1. 194. 40 pages.

Cain, S.A. 1931. Ecological studies of the vegetation of the Great Snoky Mountains of North Carolina and Tennessee. 1. Soil reaction and plant distribution. Bot. Gaz. 91:22-41.

Cain, S.A. and R.C. Friesner. 1929. Some ecological factors in secondary successions: Upland hardwoods. Butler U. Bot. Studies 1:17-28.

Cary, A. 1902-03. The management of pulpwood forests. IN Current literature and review of Report of the Third Annual Meeting of the Canadian Forestry Association, 1902, 128 pages. J. Forestry 1:67-69.

Chandler, R.F. 1939. Cation exchange properties of certain forest soils in the Adirondack section. J. Agr. Res. 59:491-505.

Charlson, R.J. and H. Rodhe. 1982. Factors controlling the acidity of natural rainwater. Nature 295:683-685.

Chittenden, A.K. 1905. Forest conditions of northern New Hampshire. USDA Bur. For. Bul1. 55. 100 pages.

Christophersen, N., A.0. Stuanes, and R.F. Wright. 1982. Runoff chemistry at a mini-catchment watered with "unpolluted precipitation". Nordic Hydro 1. 13:115-128.

Clalyson, M. 1979. Forests in the 1ong sweep of American history. Science 204:1168-1174.

Clayton, J.S. W.A. Ehrlich, D.B. Cann, J.H. Day, and I.B. Marshall. 1977. Soils of Canada. Vol. 1 - Soil Report. Can. Dept. Agr. 243 pages.

Clement, P. 1966. Snow water acidity in Wyoming. Water Resources Series No. 3, Water Resour. Res. Inst., U. of Wyoming, Laramie. 10 pages. 
Cline, M.G. and R.L. Marsha71. 1976. Soils of Nev York Landscapes. Corne11 Information Bu11. 119. 61 pages, 1 map.

Cogbi11, C.V. 1976. The history and character of acid precipitation in eastern North America, pp. 363-370. IN Proc. First Int. Symp. on Acid Precipitation and the Forest Ecosystem. USDA For. Serv. Gen. Tech. Rep. NE-23. 1074 pages.

Cole, D.W. and D.W. Johnson. 1977. Atmospheric sulfate additions and cation leaching in a Douglas Fir ecosystem. Water Resour. Res. 13:313-317.

Covington, W.W. 1981. Changes in forest floor organic matter and nutrient content following clear cutting in northern hardwoods. Ecology 62:41-48.

Cowling, E.B. 1980. An historical resumé of progress in scientific and public understanding of acid precipitation and its biological consequences. FR18/80, SNSF-project, 0slo. 29 pages.

Cowling, E.B. 1982. Acid precipitation in historical perspective. Environ. Sci. Techno1. 16:110A-123A.

Cronan, C.S. 1978. Solution Chemistry of a New Hampshire Subalpine Ecosystem. Biogeochemical Patterns and Processes. Ph.D. Thesis, Dartmouth College. 248 pages.

Cronan, C.S., W.A. Reiners, R.C. Reynolds, and G.E. Lang. 1978 Forest floor leaching: Contributions from mineral, organic, and carbonic acids in Nev Hampshire subalpine forests. Science 200:309-311.

Cronan, C.S. and C.E. Schofield. 1979. Aluminum leaching response to acid precipitation: effects on high-elevation watersheds in the Northeast. Science 204:304-306.

Dana, S.T. 1930. Timber growing and logging practices in the Northeast. USDA Tech. Bu11. 166. 112 pages.

Defebaugh, J.E. 1906. History of the Lumber Industry of America. Vo1. 1 The American Lumberman, Chicago. 559 pages.

Defebaugh, J.E. 1907. History of the Lumber Industry of America. Vol. 2 The American Lumberman, Chicago. 655 pages.

Dickson, D.R. and T.M. Bolyers. 1976. Forest statistics for Connecticut. USDA For. Serv. Resour. Bul1. NE-44. 40 pages.

Dickson, W. 1980. Properties of acidified waters, pp. 75-83. IN D. Drabløs and A. Tollan [ed.] Ecological Impact of Acid Precipitation. SNSFproject. 0s1o. 383 pages.

Diebold, C.H. 1941. Effect of fire and logging upon the depth of the forest floor in the Adirondack region. Soil Sci. Soc. Amer. Proc. $6: 409-413$.

Dillon, P.J., D.S. Jeffries, W. Snyder, R. Reid, N.D. Yan, D. Evans, J. Moss, and W.A. Scheider. 1978. Acidic precipitation in south-central Ontario: Recent observations. J. Fish. Res. Board Can. 35:809-815. 
Dodge, J.R. 1891. Album of Agricultural Statistics of the United States. USDA, Washington, DC. 8 pages plus 16 maps and tables.

Donahue, R.L. 1940. Forest-site quantity studies in the Adirondacks 1. Tree growth as related to soil morphology. Cornell U. Agr. Exp. Sta. Memoir 229. 44 pages.

Dovland, H., E. Joranger, and A. Semb. 1976. Deposition of air pollutants in Norway, pp. 15-35. IN F.H. Braekke [ed.] Impact of Acid Precipitation on Forest and Freshwater Ecosystens in Norway. FR6/76, SNSF-project, 0slo. 111 pages.

Drabløs, D. and I. Sevaldrud. 1980. Lake acidification, fist damage and utilization of outfields. A comparative survey of six highland areas, southeastern Norway, pp. 354-355. IN D. Drablos and A. Tollan [ed.] Ecological Impact of Acid Precipitation. SNSF-project, 0slo. 383 pages.

Drabløs, D, I. Sevaldrud, and J.A. Timberlid. 1980. Historical 1and-use changes related to fish status development in different areas in southern Norway, pp. 367-369. IN D. Drablos and A. Tollan [ed.] Ecological Impact of Acid Precipitation. SNSF-project, 0slo. 383 pages.

Driscol1, C.T. and G.E. Likens. 1982. Hydrogen ion budget of an aggrading forest ecosystem. Tellus $34: 282-292$.

Dwyer, J.F. 1976. The Adirondack Park: A century of controversy. J. Soi1 Water Conserv. $31: 214-217$.

Eaton, J.S., G.E. Likens, and F.H. Bormann. 1973. Throughfall and stemflow chemistry in a northern hardwood forest. J. Ecol. 61:495-508.

Eaton, J.S., G.E. Likens, and F.H. Bormann. 1978. The input of gaseous and particulate sulfur to a forest ecosystem. Tellus 30:546-551.

Eaton, T.H. and R.F. Chandler. 1942. The fauna of forest-humus layers in New York. Cornell U. Agr. Exp. Sta. Memoir 247. 26 pages.

Egner, H. and E. Eriksson. 1955. Current data on the chemical composition of air and precipitation. Tellus 7:134-139.

EPA. 1980a. Acid Rain, Vo7. 1. (The first of a series of quarterly acid rain status reports). 4 pages.

EPA. 1980b. Acid Rain. EPA-600/9-79-036. 36 pages.

Eschner, A.R. and D.R. Satterlund. 1966. Forest protection and streamflow! from an Adirondack watershed. Water Resour. Res. 2:765-783.

Fahey, T.J. and W.A. Reiners. 1981. Fire in the forests of Maine and New! Hampshire. Bu11. Torrey Bot. C1ub 108:362-373.

Ferguson, R.H. and V.S. Jensen. 1963. The timber resources of New Hampshire. USDA For. Serv. Resour. Rep. NE-1. 46 pages. 
Ferguson, R.H. and N.P. Kingsley. 1972. The timber resources of Maine. USDA For. Serv. Resour. Bu11. NE-26. 129 pages.

Fernow, B.E. 1902-03. The outlook of the timber supply in the United States. J. Forestry 1:87-93.

Fox, W.F. 1902. A history of the lumber industry in the State of New York. USDA Bur. For. Bu71. 34. 59 pagés.

Frank, R.M. and J.C. Bjorkbon. 1973. A silvicultural guide for spruce-fir in the Northeast. USDA For. Serv. Gen. Tech. Rep. NE-6. 29 pages.

Frink, C.R. 1973. Aluminum chemistry in acid sulfate soils, pp. 131-168. IN H. Dost [ed.] Acid Sulfate Soils. Vol. 1. Introductory Papers and Bibliography. Publ. 18 of the International Institute for Land Reclamation and Improvement, Wageningen, Netherlands. 295 pages.

Frink, C.R. and W.A. Norve11. 1984. Chemical and physical properties of Connecticut 1akes. CT Agr. Exp. Sta. Bu17.817. In press.

Frink, C.R. and M. Peech. 1962. The solubility of gibbsite in aqueous solutions and soil extracts. Soil Sci. Soc. Amer. Proc. 26:346-347.

Frink, C.R. and G.K. Voigt. 1976. Potential effects of acid precipitation on soils in the humid temperate zone, pp. 685-709. IN Proc. First Int. Symp. on Acid Precipitation and the Forest Ecosystem. USDA For. Serv. Gen. Tech. Rep. NE-23. 1074 pages.

Galloway, J.N., C.L. Schofield, G.R. Hendrey, E.R. Altwicker, and D.E. Troutman. 1980a. An analysis of lake acidification using annual budgets, pp. 254-255. IN D. Drabløs and A. Tollan [ed.] Ecological Impact of Acid Precipitation. SNSF-project, 0s10. 383 pages.

Galloway, J.N., C.L. Schofield, G.R. Hendrey, N.E. Peters, and A.H. Johannes. 1980b. Sources of acidity in three lakes acidified during snomelt, pp. 264265. IN D. Drabløs and A. Tollan [ed.] Ecological Impact of Acid Precipitation. SNSF-project, 0slo. 383 pages.

Garrels, R.M. and C.L. Christ. 1965. Solutions, Minerals, and Equilibria. Häper and Row. 450 pages.

Ghosh, K. and M. Schnitzer. 1980. Macromolecular structures of humic substances. Soi] Sci. 129:266-276.

Gjessing, E.T., A. Henriksen, M. Johannessen, and R.F. Wright. 1976. Effects of acid precipitation on freshwater chemistry, pp. 65-85. IN F.H. Braekke [ed.] Impact of Acid Precipitation on Forest and Freshwater Ecosystems in Norway. FR6/76, SNSF-project, 0s7o. 111 pages.

Glazovskaya, M.A. 1968. Geochemical landscapes and types of geochemical soil sequences. Ninth Int. Cong. Soil Sci. Trans. 4:303-312.

Glazovskaya, M.A. 1970. Types of geochemical soil catenas. Soviet Geography. 11:235-245. Translated from: Vestnik Moskovskogo Universiteta, Geografiya. 1969. No. 5, pp. 3-11. 
Glover, G.M., A.S. Kallend, A.R.W. Marsh, and A.H. Webb. 1980. Ion relationships in acid precipitation and stream chemistry, pp. 95-109. IN T.C. Hutchinson and M. Havas [ed.] Effects of Acid Precipitation on Terrestrial Ecosystems. Plenum Press. 654 pages.

Gorham, E. 1957. The chemical composition of lake waters in Halifax County, Nova Scotia. Limno1. Oceanogr. 2:12-21.

Gorham, E. 1958. Free acid in British soils. Nature 181:106.

Graustein, W.C. 1981. The Effects of Forest Vegetation on Solute Acquisition and Chemical Weathering: A Study of the Tesuque Watersheds Near Santa Fe, New Mexico. Ph.D. Thesis, Yale U. 645 pages.

Griffith, B.G., E.W. Hartwell, and T.E. Shaw. 1930. The evolution of soils as affected by the old field white pine-mixed hardwood succession in central New England. Harvard For. Bu11. No. 15. 82 pages.

Hanks, J.P. 1971. Secondary succession and soils on the inner coastal plain of New Jersey. Bui1. Torrey Bot. Club 98:315-327.

Hansen, D.A. 1981. Acid rain: How long and how bad? Electrical Perspectives, Fa11, 1981. pp. 17-24.

Hardy, F. 1926. The role of aluminum in soil infertility and toxicity. J. Agr. Sci. 16:616-631.

Hargrove, W.L. and G.W. Thomas. 1981. Effect of organic matter on exchangeable aluminum and plant growth in acid soils, pp. 15]-166. IN Chemistry in the Soil Environment. Amer. Soc. Agron. Spec. Pub. No. 40. Madison, WI. 259 pages.

Harper, R.M. 1918. Changes in the forest area of New England in three centuries, J. Forestry 16:442-452.

Hart, A.C. 1964. Spruce-fir silviculture in northern New England. Soc. Amer. Foresters Proc. 1963:107-110.

Hart, G. 1961. Humus depths under cut and uncut northern hardwood forests. USDA For. Serv. NE For. Exp. Sta. For. Res. Note 113. 4 pages.

Hart, G., R.E. Leonard, and R.S. Pierce. 1962. Leaf fall, humus depth, and soil frost in a northern hardwood forest. USDA For. Serv. NE For. Exp. Sta. For. Res. Note 131. 3 pages.

Hawley, R.C. and A.F. Hawes. 1912. Forestry in New England. John Wiley \& Sons. 479 pages.

Hayes, M.H.B. and R.S. Swift. 1978. The chemistry of soil organic colloids, pp. 179-320. IN D.J. Greenland and M.H.B. Hayes [ed.] The Chemistry of Soil Constituents. Wiley-Interscience. 469 pages. 
Heimath, B. 1933. Untersuchungen über schwefelsäurevorkommen in saurem waldhumus (Investigation of the occurrence of sulfuric acid in acid forest humus). Z. Pflanzenernahr. dung. bodenk. A. 31:229-251.

Heimburger, C.C. 1934. Forest-type studies in the Adirondack Region. Cornel1 U. Agr. Exp. Sta. Memoir 165. 122 pages.

Henriksen, A. and H.M. Seip. i980. Strong and weak acids in surface waters of southern Norway and southwestern Scot1and. FR17/80, SNSF-project, 0slo. 26 pages.

Hicock, H.W. 1956. The Cathedral Pines, pp. 25-28. IN Six Points of Especial Botanical Interest in Connecticut. Bulletin No. 9 of the Connecticut Arboretum, Connecticut College, New London. 32 pages, 1 map.

Hicock, H.W., M.F. Morgan, H.J.Lutz, H. Bu11, and H.A. Lunt. 1931. The relation of forest composition and rate of growth to certain soil characters. CT Agr. Exp. Sta. Bu17. 330. pp. 677-750.

Hileman, B. 1981. Acid precipitation. Environ. Sci. Techno1. 15:1719-1124.

Hileman, B. 1982. Acid deposition. Environ. Sci. Techno1. 16:323A-327A.

Hopkins, A.D. 1899. Report on investigations to determine the cause of unhealthiy conditions of the spruce and pine from 1880-1893. WV Agr. Exp. Sta. Bu11. 56. pp. 195-461.

Hornbeck, J.W., G.E. Likens, and J.S. Eaton. 1976. Seasonal patterns in acidity of precipitation and their implications for forest stream ecosystems, pp. 597-609. IN Proc. First Int. Symp. on Acid Precipitation and the Forest Ecosystem. USDA For. Serv. Gen. Tech. Rep. NE-23. 1074 pages.

Hough, A.F. 1943. Soil factors and stand history in a virgin forest valley on the northern Allegheny Plateau. Soil Sci. 56:19-28.

Hoyle, M.C. 1965. Forest soils in the White Mountains: What are forest soils? Reprint from NH For. Notes, Summer 1965. 6 pages.

Hoyle, M.C. 1973. Nature and properties of some forest soils in the White Mountains of New Hampshire. USDA For. Serv. Res. Paper NE-260. 18 pages.

Hsu, P.H. and C.I. Rich. 1960. Aluminum fixation in a synthetic cation exchanger. Soil Sci. Soc. Amer. Proc. 24:21-25.

Hutchinson, G.E. 1957. A Treatise on Limnology, Volume 1. Geography, Physics, and Chemistry. John Wiley \& Sons. 1015 pages.

Jackson, M.L. 1963. Aluminum bonding in soils: A unifying principle in soil science. Soil Sci. Soc. Amer. Proc. 27:1-10.

Jenkinson, D.S. 1971. The accumulation of organic matter in soil 1eft uncultivated, pp. 113-137. Rothhamsted Exp. Sta. Rep. for 1970.

Part 2. 259 pages. 
Jenny, H. 1941. Factors of Soil Formation. MCGraw-Hill. 281 pages. Jenny, H. 1961. Reflections on the soil acidity merry-go-round. Soil Sci. Soc. Amer. Proc. 25:428-432.

Joffe, J.S. 1930. Experiments on the movement of iron and aluminum in the soil. Proc. Second Int. Cong. Soil Sci. 2:135-145.

Joffe, J.S. 1933. Lysimeter studies: II. The movement and translocation of soit constituents in the soil profile. Soil Sci. 35:239-257.

Joffe, J.S. and H.C. McLean. 1928a. Colloidal behavior of soils and soil fertility: IV. Anion effect on the precipitation reactions and degree of dispersion of aluminum and iron hydroxides. Soil Sci. 26-47-59.

Joffe, J.S. and H.C. McLean. 1928b. Colloidal behavior of soils and soil fertility: $V$. The distribution of soluble and colloidal iron and aluminum in soils. Soil Sci. 26:317-325.

Johannes, A.H. and E.R. Altwicker. 1980. Atmospheric inputs to three Adirondack lake watersheds, pp. 256-257. IN D. Drabløs and A. Tollan [ed.] Ecological Impact of Acid Precipitation. SNSF-Project, 0slo. 383 pages.

Johannessen, M. and A. Henriksen. 1977. Chemistry of snowmelt water: Changes in concentration during melting. FR11/77, SNSF-Project, 0s10. 11 pages.

Johansson, 0. 1959. On sulfur problems in Swedish agriculture. Kungl. Lantbruks. Anna1. 25:57-169.

Johnson, D.W., J. Turner, and J.M. Kelly. 1982. The effects of acid rain on forest nutrient status. Water Resour. Res. 18:449-461.

Johnson, N.M. 1979. Acid rain: neutralization within the Hubbard Brook ecosystem and regional implications. Science 204:497-499.

Johnson, N.M. 1982. Acid rain neutralization by geologic materials, pp. 490-493. IN Amer. Chem. Soc., Div. Environ. Chem. 185th Nat1. Meeting, Las Vegas, Nevada, March 28-Apri1 2, 1982. 22(No. 1). 635 pages.

Johnson, N.M., C.T. Driscol1, J.S. Eaton, G.E. Likens, and W.H. McDowel1. 1981. "Acid Rain", dissolved aluminum and chemical weathering at the Hubbard Brook Experimental Forest, New Hampshire. Geochim. Cosmochim. Acta 45:1421-1437.

Johnson, N.M., G.E. Likens, F.H. Bormann, and R.S. Pierce. 1968. Rate of chemical weathering of silicate materials in New Hampshire. Geochim. Cosmochim. Acta 32:531-545.

Johnson, N.M., G.E. Likens, F.H. Bormann, D.W. Fisher, and R.S. Pierce. 1969. A working model for the variation in stream water chemistry at the Hubbard Brook Experimental Forest, New Hampshire. Water Resour. Res. 5:1353-1363. 
Johnson, N.M., R.C. Reynolds, and G.E. Likens. 1972. Atmospheric sulfur: Its effect on the chemical weathering of Nev England. Science 177:514-516.

Kerekes, J.J. 1980. Preliminary characterization of three lake basins sensitive to acid precipitation in Nova Scotia, Canada, pp. 232-233. IN D. Drabløs and A. Tollan [ed.] Ecological Impact of Acid Precipitation. SNSF-project, 0s7o. 383 pages.

Kerndorff, H. and M. Schnitzer. 1980. Sorption of metals on humic acids. Geochim. Cosmochim. Acta 44:1701-1708.

Kerr, R.A. 1981. Is all acid rain polluted? Science 212:1014.

Kings7ey, N.P. 1971. Pulpwood in the Northeast: Past, present, and future. USDA For. Serv. Resour. Bu11. NE-23. 21 pages.

Kingsley, N.P. 1974. The timber resources of southern New England. USDA For. Serv. Resour. Bu11. NE-36. 50 pages.

Kingsley, N.P. 1977. The Forest Resources of Vermont. USDA For. Serv. Resour. Bu11. NE-46. 58 pages.

Kittredge, J. and H.C. Belyea. 1923. Reproduction with fire protection in the Adirondacks. J. Forestry 21:784-787.

Knechte1, A. 1902-03. Natural production in the Adirondack forests. J. Forestry 1:50-55.

Knechtel, A. 1903-04. Forest fires in the Adirondacks. J. Forestry 2:2-13.

Kohnke, H., F.R. Dreibelbis, and J.M. Davidson. 1940. A survey and discussion of lysimeters and a bibliography on their construction and performance. USDA Misc. Publ. 372. 68 pages.

Korstian, C.F. 1937. Perpetuation of spruce on cut-over and burned 1ands in the higher southern Appalachian Mountains. Ecol. Monogr. 7:125-167.

Krebs, R.D. and J.C.F. Tedrow. 1957. Genesis of three soils derived from Wisconsin till in New Jersey. Soil Sci. 83:207-218.

Krug, E.C. 1981. Geochemistry of Pedogenic Bog Iron and Concretion Formation. Ph.D. Thesis, Rutgers U. 227 pages.

Låg, J. 1968. Relationships between the chemical composition of the precipitation and the contents of exchangeable ions in the humus layer of natural soils. Acta Agr. Scand. 18:148-152.

Låg, J. 1976. Influence of soils on freshwater, pp. 21-25. Reprint from S. Skreslet, R. Leineb $\varnothing$, J.B.L. Matthews, and E. Sakshaug [ed.] Proceedings from a symposium on the influence of fresh-water outflow on biological processes in fjords and coastal waters, 22-25 April, 1974, Geilo, Norway. Association of Norwegian Oceanographers, 0sio. 
$\mathrm{LIg}$, J. 1979. Jordsmonnkart over Norge (Scale 1:2,000,000). Norges Landbruks.

Leivestad, H., G. Hendrey, I.P. Muniz, and E. Snekvik. 1976. Effects of acid precipitation on freshwater organisms, pp. 87-111. IN Impact of Acid Precipitation on Forest and Freshwater Ecosystems in Norway. FR6/76, SNSF-project. 111 pages.

Lewis, T. and L.M. Lavkulich. 1972. Some folisols in the Vancouver area, British Columbia. Can. J. Soil Sci. 52:91-98.

Likens, G.E. 1972. The chemistry of precipitation in the Central Finger Lakes Region. Cornell U. Water Resour. and Marine Sci. Ctr. Tech. Rep. 50. 47 pages, 14 figures.

Likens, G.E. November 22, 1976. Acid Precipitation. Chem. Eng. News. pp. $29-31,35-37,42-44$.

Likens, G.E., and F.H. Bormann. 1974. Acid rain: A serious regional environmental problem. Science 184:1176-1179.

Likens, G.E., F.H. Bormann, N.M. Johnson, D.W. Fisher, and R.S. Pierce. 1970. Effects of forest cutting and herbicide treatment on nutrient budgets in the Hubbard Brook watershed-ecosystem. Ecol. Monogr. 40:23-47.

Likens, G.E., F.H. Bormann, R.S. Pjerce, J.S. Eaton, and N.M. Johnson. 1977. Biogeochemistry of a Forested Ecosystem. Springer-Verlag. 146 pages.

Likens, G.E., F.H. Bormann, R.S. Pierce, and W.A. Reiners. 1978. Recovery of a deforested ecosystem. Science 199:492-496.

Likens, G.E., R.F. Wright, J.N. Galloway, and T.J. Butler. 1979. Acid rain. Scientific American 241(4):43-51.

Lindsay, W.L., M. Peech, and J.S. Clark. 1959. Determination of aluminum ion activity in soil extracts. Soil Sci. Soc. Amer. Proc. 23:266-269.

Loucks, O.L., R.W. Miller, and T.V. Armentano. 1982. Regional Assessment of Aquatic Resources at Risk from Acidic Deposition. The Institute of Ecology, Indianapolis, Indiana. 121 pages.

Lu17, H.W. 1959. Humus depth in the Northeast. J. Forestry 57:905-909.

Lunt, H.A. 1932. Profile characteristics of New England forest soils. CT Agr. Exp. Sta. Bu11. 342. pp. 743-836.

Lunt, H.A. 1938. Forest soil problems in New England. Ecology 19:50-56.

Lunt, H.A. 1941. Forest 1ysimeter studies under hardwoods. CT Agr. Exp. Sta. Bul1. 449. pp. 519-572.

Lunt, H.A. 1948. The forest soils of Connecticut. CT Agr. Exp. Sta. Bu11. 523. 93 pages. 
Lunt, H.A. 1951. Liming and twenty years of litter raking and burning under red (and white) pine. Soil Sci. Soc. Amer. Proc. 15:381-390.

Lutz, H.J. and R.F. Chandler. 1946. Forest Soils. John Wiley \& Sons. 514 pages.

MacDonald, A. 1925. Policy for forest land acquisition by New York State. J. Forestry 23: 457-459.

Mader, D.L., H.W. Lu11, and E.I. Swenson. 1977. Humus accumulation in hardwood stands in the Northeast. MA Agr. Exp. Sta. Res. Bull. 648. 37 pages.

Marbut, C.F. 1951. Soils: Their Genesis and Classification (a memorial volume of lectures given in the Graduate School of the United States Department of Agriculture in 1928). Soil Sci. Soc. of Amer. Pub7. 134 pages.

Marshall, R. 1925. Recreational limitations to silviculture in the Adirondacks. J. Forestry 23:173-178.

Mattson, S. and $Y$. Gustafsson. 1934. The chemical characteristics of soir profiles: 1. The podzol. Kung1. Lantbruks. Annal. 1:33-68, 1 plate.

Mattson, S. and J.B. Hester. 1933. The laws of soil colloidal behavior: XII. The amphoteric nature of soils in relation to aluminum toxicity. Soi1 Sci. 36:229-244.

Mattson, S. and E. Koutler-Andersson. 1942. The electro-chemistry of soil formation: V. A lysimeter study of podzolic solvation and precipitation. Kung1. Lantbruks. Anna1. 10:241-257.

Mattson, S. and E. Koutler-Andersson. 1946. The acid-base condition in vegetation, litter and humus: IX. Forms of bases. Kungl. Lantbruks. Anna1. 13:153-178.

McCarthy, E.F. 1919. Observations on unburned cut-over 1 ands in the Adirondacks. J. Forestry 17:386-397.

McCo11, J.G., B.A. Browne, and M.K. Firestone. 1982. Acid rain mobilization of aluminum and organic carbon, p. 178. IN Agronomy Abstracts, 1982 Annual Meetings. Amer. Soc. Agron., Madison, WI. 294 pages.

McFee, W.W., J.M. Kelly, and R.H. Beck. 1976. Acid precipitation effects on soil $\mathrm{pH}$ and base saturation of exchange sites, pp. 725-735. IN Proc. First Int. Symp. on Acid Precipitation and the Forest Ecosystem. USDA For. Serv. Gen. Tech. Rep. Ne-23. 1074 pages.

McIntosh, R.P. and R.T. Hurley. 1964. The spruce-fir forests of the Catski11 Mountains. Ecology 45:374-326.

Meyer, W.H. 1929. Yields of second-growth spruce and fir in the Northeast. USDA Tech. Bu11. 142. 52 pages. 
Minckler, L.S. 1945. Reforestation in the spruce type in the southern Appalachians. J. Forestry 43:349-356.

Mollitor, A.V. and K.R. Berg. 1980. Section 3: Effects of acid precipitation on forest soils, 80 pages. IN Actual and Potential Effects of Acid Precipitation on a Forest Ecosystem. NY State Energy Research and Development Authority.

Mollitor, A.V. and D.J. Raynal. 1982. Acid precipitation and ionic movements in Adirondack forest soils. Soil Sci. Soc. Amer. J. 46:137-141.

Monahan, R.S. 1933. Timberline. Appalachia 19:401-426.

Morgan, M.F. 1931. Effect of silvicultural practices, forest removal and reforestation upon soil character. Amer. Soil Surv. Assoc. Bul1. 12:49.

Morrison, I.K. 1981. Effect of simulated acid precipitation on composition of percolate from reconstructed profiles of two northern Ontario forest soils. Can. For. Serv. Res. Notes 1(2):6-8.

Mortvedt, J.J., P.M. Giordano, and W.L.Lindsay [ed.]. 1972. Micronutrients in Agriculture. Soil Sci. Soc. Amer., Madison, WI. 666 pages.

Moss, A.E. 1916. A forest survey of Connecticut, pp. 197-232, plus 4 maps. IN The Thirty-ninth Ann. Rep. of the CT Agr. Exp. Sta., 1915. 539 pages.

Mülder, J. 1980. The Neutralization of Acid Rain in the Hubbard Brook Experimental Forest, New Hampshire, USA. Wageningen, Netherlands. Unpublished Report. 27 pages plus 5 appendices.

Murphy, L.S. 1917. The red spruce: Its growth and management. USDA Buit. 544. 100 pages.

National Research Council. 1981. Atmosphere-Biosphere Interactions: Toward a Better Understanding of the Ecological Consequences of Fossil Fue 1 Combustion. Committee on the Atmosphere and the Biosphere. National Academy of Sciences, Washington, DC. 263 pages.

New York State Department of Environmental Conservation (sponsor). 1982. Proceedings of the Acid Precipitation Research Needs Conference. SUNY, Syracuse, NY. 88 pages.

Nihlgard, B. 1971. Pedological influence of spruce planted on former beech forest soils in Scania, South Sweden. 0ikos 22:302-314.

Norvel1, W.A. and C.R. Frink. 1975. Water chemistry and fertility of twenty-three Connecticut 1akes. CT Agr. Exp. Sta. Bu11. 759. 45 pages.

Odén, S. 1976. The acidity problen -- an outline of concepts, pp. 1-36 IN Proc. First Int. Symp. on Acid Precipitation and the Forest Ecosystem. USDA For. Serv. Gen. Tech. Rep. NE-23. 1074 pages. 
Dosting, H.J. and W.D. Billings. 1951. A compariscn of virgin spruce-fir forest in the northern and southern Appalachian system. Ecology 32:84-103.

0osting, H.J. and J.F. Reed. 1944. Ecological composition of pulpwood forests in northwestern Maine. Amer. Mid. Nat. 31:182-210.

Overrein, L.N. 1972. Sulfur pollution patterns observed: Leaching of calcium in forest soil determined. Ambio. 1:145-147.

Overrein, L.N., H.M. Seip, and A. Tol1an. 1980. Acid Precipitation - effects on forest and fish. Final Report of the SNSF-project 1972-1980. FR19/80 SNSF-project, Oslo. 175 pages.

Pack, D.H. 1980. Precipitation chemistry patterns: A two-network data set. Science 208:1143-1145.

Patrick, R., V.P. Binetti, and S.G. Halterman. 1981. Acid lakes from natural and anthropogenic causes. Science 211:446-448.

Patrick, R., B. Matson, and L. Anderson. 1979. Streams and lakes in the Pine Barrens, pp. 169-193. IN T.T. Forman [ed.] Pine Barrens. Ecosystem and Landscape. Academic Press. 601 pages.

Pearson, F.J. and D.W. Fisher. 1971. Chemical composition of atmospheric precipitation in the northeastern United States. USGS Water Supply Paper 1535-P. 23 pages.

Pearson, R.W. and F. Adams [ed.]. 1967. Soit Acidity and Liming. Agronomy Series No. 12. Amer. Soc. of Agron., Madison, WI. 274 pages.

Peters, N.E., R.A. Schroeder, and D.E. Troutman. 1982. Temporal trends in the acidity of precipitation and surface waters of New York. USGS Water-Supply Paper 2188. 35 pages.

Petersen, L. 1976. Podzols and Podzolization. DSR Forlag, Copenhagen. 293 pages.

Pfeiffer, M.H. and P.J. Festa. 1980. Acidity status of 1akes in the Adirondack region of New York in relation to fish resources. NY Dept. of Environ. Conserv. 36 pages plus 3 appendices.

Pilgrim, S.A.L. and R.D. Harter. 1977. Spodic horizon characteristics of some forest soils in the White Mountains, New Hampshire. NH Agr. Exp. Sta. Bu11. 507. 19 pages, appendix.

Pionke, H.B., R.L. Hendrick, and B.J. Chamberlin. 1982. Sleepers River Research Watershed, Danvil1e, Vermont, pp. 146-153. IN The Quality of Agricultural Research Service Watershed and Plot Data, USDA Agr. Res. Serv. Agr. Rev. and Manuals. ARM-W-37/August, 1982. 168 pages.

Plice, M.J. 1934. Acidity, antacid buffering, and nutrient content of forest litter in relation to humus and soil. Cornell U. Agr. Exp. Sta. Memoir 166. 32 pages. 
Potapov, A.I. 1933. Soil acidity as a phytopedological factor. Soil Sci. $35: 55-73$.

Provan, D.M.J., R. Sorensen, and J.L\&g. 1969. Properties of some soils developed on limestone bedrock in the 0slo region. Meld. Norges Landbruks. Vol. 48 (No. 22), 29 pages.

Richard, J.A. and R.F. Chandler. 1943. Some physical and chemical properties of mature podzol profiles. Soil Sci. Soc. Amer. Proc. 8:379-383.

Ritchie, G.S.P. and A.M. Posner. 1982. The effect of pH and metal binding on the transport properties of humic acids. J. Soil Sci. 33:233-247.

Rode, A.A. 1962. Soil Science. Translated from the 1955 Russian publication by the Israel Program for Scientific Translations, Jerusalem. US Dept. of Commerce, Washington, DC. 517 pages.

Rome11, L.G. 1932. Mull and duff as biotic equilibria. Soil Sci. 34:161-188.

Rosenquist, I. Th. 1978. Alternative sources for acidification of river water in Norway. Sci. Total Environ. 10:39-49.

Rosenqvist, I. Th. 1980. Influence of forest vegetation and agriculture on the acidity of fresh water, pp. 56-79. IN J.R. Pfafflin and E.N. Ziegler [ed.] Advances in Environmental Science and Engineering. Vol 3. Gordon and Breach Science Publishers. 224 pages.

Rues]atten, H.G. and P. Jørgensen. 1978. Interaction between bedrock and precipitation at temperatures close to $0^{\circ} \mathrm{C}$. Nordic Hydrol. 9:1-6.

Russe11, E.W.B. 1981. Vegetation of northern New Jersey before European settlement. Amer. Mid. Nat. 105:1-12.

Salisbury, E.J. 1922. Stratification and hydrogen-ion concentration of the soil in relation to leaching and plant succession with special reference to woodlands. J. Ecol. 9:220-240.

Salisbury, E.J. 1925. Note on the edaphic succesion in some dune soils with special reference to the time factor. J. Ecol. 13:322-328.

Samoilov, 0. Ya. 1965. Structure of Aqueous Electrolyte Solutions and the Hydration of Ions, a translation from the 1957 Russian publication by D.J.G. Ives. A special research report/authorized translation from the Russian Consultants Bureau, New York. 185 pages.

Sanchez, P.A., D.E. Bandy, J.H. Villachica, and J.J. Nicholaides. 1982. Amazon basin soils: Management for continuous crop production. Science 216:821-827.

Schnitzer, M. and J.G. Desjardins. 1969. Chemical characteristics of a natural soil leachate from a humic podzol. Can. J. Soil Sci. 49:151-158. 
Schnitzer, M. and E.H. Hansen. 1970. Organo-metallic interactions in soils: 8. An evaluation of methods for the determination of stability constants of metal-fulvic acid complexes. Soil Sci. 109:333-340.

Schnitzer, M. and S.I.M. Skinner. 1963a. Organo-metallic interactions in soils: 1. Reactions between a number of metal ions and the organic matter of a podzol Bh horizon. Soil Sci. 96:86-93.

Schnitzer, M. and S.I.M. Skinner. 1963b. Organo-metallic interactions in soils: 2. Reactions between different forms of iron and aluminum and the organic matter of a podzol Bh horizon. Soil Sci. 96:181-186.

Schofield, C.L. 1976a. Acid precipitation: Effects on fish. Ambio. 5:228-230.

Schofield, C.L. 1976b. Lake acidification in the Adirondack Mountains of New York: Causes and consequences, p. 477. IN Proc. First Int. Symp. on Acid Precipitation and the Forest Ecosystem. USDA For. Serv. Gen. Tech. Rep. NE-23. 1074 pages.

Secretary of the Connecticut Board of Agriculture. 1877. Tenth Annual Report of the Secretary of the Connecticut Board of Agriculture. 1876-7. 452 pages.

Secretary of the Connecticut Board of Agriculture. 1878. Eleventh Annual Report of the Secretary of the Connecticut Board of Agriculture. 1877-8. 410 pages.

Secretary of the Connecticut Board of Agriculture. 1901. Thirty-Fourth Annual Report of the Secretary of the Connecticut Board of Agriculture. 1900. State of CT Pub. Doc. No. 18. 370 pages, plus index.

Secretary of the Connecticut Board of Agriculture. 1914. Forty-Sixth Annual Report of the Secretary of the Connnecticut State Board of Agriculture. 1913. State of CT Pub. Doc. No. 19. 193 pages.

Seip, H.M. 1980a. Acidification of freshwater - Sources and mechanisms, pp. 358-366. IN D. Drabløs and A. Tollan [ed.] Ecological Impact of Acid Precipitation. SNSF-project, 0slo. 383 pages.

Seip, H.M. 1980b. Acid snow-snowpack chemistry and snowmelt, pp.77-94. IN T.C. Hutchinson and M. Havas [ed.] Effects of Acid Precipitation on Terrestrial Ecosystems. Plenum Press. 654 pages.

Seip, H.M., G. Abrahamsen, E.T. Gjessing, and A. Stuanes. 1979a. Studies of soil-, precipitation- and run-off chemistry in six small natural plots ("mini-catchments"). IR46/79, SNSF-project, 0slo. 62 pages。

Seip, H.M., E.T. Gjessing, and H. Kamben. 1979b. Importance of the composition of the precipitation for the $\mathrm{pH}$ in runoff-experiments with artifical precipitation on partly soil-covered "mini-catchments". IR47/79, SNSFproject, 0slo. 34 pages.

Seip, H.M., S. Andersen, and B. Halsvik. 1980. Snowmelt studied in a minicatchment with neutralized snow. IR65/80, SNSF-project. 20 pages. 
Siccama, T.G. 1968. Altitudinal Distribution of Forest Vegetation in Relation to Soil and Climate on the Slopes of the Green Mountains. Ph.D. Thesis. U. of Vermont.

Siccana, T.G. 1974. Vegetation, soil, and climate on the Green Mountains of Vermont. Ecol. Monogr. 44:325-349.

Singh, B.R., G. Abrahamsen, and A. Stuanes. 1980. Effect of simulated acid rain on sulfate movement in acid forest soils. Soil Sci. Soc. Am. J. 44:75-80.

Smith, D.M. 1956. Catlin Wood, pp. 19-24. IN Six Points of Especial Botanical Interest in Connecticut. Bulletin No. 9 of the Connecticut Arboretum, Connecticut College, New London. 32 pages, 1 map.

Smith, W.H. 1981. Air Pollution and Forests. Springer-Verlag. 379 pages.

Spaulding, P. and J.R. Hansbrough. 1944. Decay in balsam fir in New England and New York. USDA Tech. Bul1. 872. 30 pages.

Stone, E.L. 1975. Effects of species on nutrient cycles and soil change. Phi1. Trans. R. Soc. Lond. B. 271:149-162.

Stuanes, A.0. 1980. Effects of acid precipitation on soil and forest 5. Release and loss of nutrients from a Norwegian forest soil due to artificial rain of varying acidity, pp. 198-199. IN D. Drabløs and A. Tollan [ed.] Ecological Impact of Acid Precipitation. SNSF-project, 0s1o. 383 pages.

Sturm, W. and J.J. Morgan. 1970. Aquatic Chemistry. Wiley-Interscience. 583 pages.

Tamm, C.0. 1976a. Acid precipitation and forest soils, pp. 681-684. IN Proc. First Int. Symp. on Acid Precipitation and the Forest Ecosystem. USDA For. Serv. Gen. Tech. Rep. NE-23. 1074 pages.

Tanm, C.0. 1976b. Acid precipitation: Biological effects in soil and on forest vegetation. Ambio. 5:235-238.

Tamm, 0. 1950. Northern Coniferous Forest Soils. Translated from Swedish and modified by M.L. Anderson and 0. Tamm from The Forest Soils of North Sweden, 1940 by 0. Tamm. Scrivener Press. 253 pages.

Thomas, G.W. 1977. Historical developments in soil chemistry: Ion exchange. Soil Sci. Soc. Amer. J. 41:230-238.

Thompson, M.E., F.C. Elder, A.R. Davis, and S. Whitlow. 1980. Evidence of acidification of rivers of Eastern Canada, pp. 244-245. IN D. Drablфs and

A. Tollan [ed.] Ecological Impact of Acid Precipitation. SNSF-project, 0slo. 383 pages.

Tobin, T.A. 1980. Acid Precipitation Patterns over Connecticut using Precipitation Observations and Sulfate, Nitrate, and Trace Metals Analysis. Masters Thesis, Yale U. 
Troedsson, T. 1980. Long-term changes of forest soils. Ann. Agr. Fenn. $19: 81-84$.

Ugolini, F.C., H. Dawson, and J. Zachara. 1977a. Direct evidence of particle migration in the soil solution of a podzol. Science 198:603-605.

Ugolini, F.C., R. Minden, H. Dawson, and J. Zachara. 1977b. An example of soil processes in the Abies amabilis zone of Central Cascades, Washington. Soil Sci. 124:291-302.

UTrich, B. 1978. Production and consumption of hydrogen ions in the ecosphere, pp. 255-282. IN T.C. Hutchinson and M. Havas [ed.] Effects of Acid Precipitation on Terrestrial Ecosystems. Plenum Press. 654 pages.

USDA. 1978. Forest Statistics of the US, 1977. Review Draft, US For. Serv. van 01phen, H. 1963. An Introduction to Clay Colloidal Chemistry. John Wiley \& Sons. 301 pages.

van Schuylenborgh, J. and M.G.M. Bruggenwert. 1965. On soil genesis in temperate humid climate. V. The formation of the "albic" and "spodic" horizon. Neth. J. Agr. Sci. 13:267-279.

Very, F.W. 1912. Devastation of forests in the White Mountains. Science $35: 31-35$.

Viro, P.J. 1974. Effects of forest fire on soil, pp. 7-45. IN T.T. Kozlowski and C.E. Ahlgren [ed.] Fire and Ecosystems. Academic Press. 542 pages.

Vitousek, P.M. 1977. The regulation of element concentrations in mountain streams in the northeastern United States. Ecol. Monogr. 47:65-87.

Vitousek, P.M., J.R. Gosz, C.C. Grier, J.M. Melillo, and W.A. Reiners. 1982. A comparative analysis of potential nitrification and nitrate mobility in forest ecosystems. Ecol. Monogr. 52:155-177.

Voigt, G.K. 1980. Acid precipitation and soil buffering capacity, pp. 53-57. IN D. Drablos and A. Tollan [ed.] Ecological Impact of Acid Precipitation. SNSF-project, 0s1o. 383 pages.

Watt, W.D., D. Scott, and S. Ray. 1979. Acidification and other chemical changes in Halifax County lakes after 21 years. Limnol. Oceanogr. 24:1154-1161.

Weeks, M.E. and D.J. Lathwe11. 1967. Crop response to 1 ime in the Northeastern United States, pp. 233-259. IN R.W. Pearson and F. Adams [ed.] Soil Acidity and Liming. Agronomy Monograph No. 12. Amer. Soc. Agron., Madison, WI. 274 pages.

Westve1d, M. 1931. Reproduction on pulpwood 1ands in the Northeast. USDA Tech. Bu11. 223. 52 pages.

Westve1d, M. 1953. Ecology and silviculture of the spruce-fir forests of eastern North America. J. Forestry 51:422-430. 
Westveld, M, R.I. Ashman, H.I. Baldwin, R.P. Holdsworth, R.S. Johnson, J.H. Lambert, H.J. Lutz, L. Swain, and M. Standish. 1956. Natural forest vegetation zones of New England. J. Forestry 54:332-338.

Wherry, E.T. 1923. A soil acidity map of a Long Island wild garden. Ecology $4: 395-401$.

Wherry, E.T. 1928. Review: Ten years of work on soil reaction as an ecological factor. Ecology 9:532.

Whittaker, R.H. 1956. Vegetation of the Great Smoky Mountains. Ecol. Monogr. $26: 1-80$.

Whittaker, R.H., F.H. Bormann, G.E. Likens, and T.G. Siccama. 1974. The Hubbard Brook ecosystem study: Forest biomass and production. Ecol. Monogr. 44:233-252.

Whittaker, R.H., G.E. Likens, F.H. Bormann, J.S. Eaton, and T.G. Siccama. 1979. The Hubbard Brook ecosystem study: Forest nutrient cycling and element behavior. Ecology 60:203-220.

Wiklander, L. 1946. Studies on ionic exchange with special reference to the conditions in soils. Kung1. Lantbruks. Annal. 14:1-171.

Wiklander, L. 1973/74. The acidification of soil by acid precipitation. Grundforbattring 26:155-164.

Wiklander, L. 1975. The role of neutral salts in the ion exchange between acid precipitation and soil. Geoderma 14:93-105.

Wiklander, L. 1980. Interaction between cations and anions influencing adsorption and leaching, pp. 239-254. IN T.C. Hutchinson and M. Havas [ed.] Effects of Acid Precipitation on Terrestrial Ecosystems. Plenum Press. 654 pages.

Winer, H.I. and E.C. Childs. 1956. An old growth hemlock stand, pp 29-32. IN Six Points of Especial Botanical Interest in Connecticut. Bu11. No. 9 of the Connecticut Arboretum. Connecticut College, New London. 32 pages, 1 map.

Winkler, E.M. 1976. Natural dust and acid rain, pp. 209-217. IN Proc. First Int. Symp. on Acid Precipitation and the Forest Ecosystem. USDA For. Serv. Gen. Tech. Rep. NE-23. 1074 pages.

Witty, J.E. and R.W. Arnold. 1970. Some Folists on Whiteface Mountain, New York. Soil Sci. Soc. Amer. Proc. 34:653-657.

Wood, T.E. 1980. Biological and Chemical Control of Phosphorus Cycling in a Northern Hardwood Forest. Ph.D. Thesis, Yale U. 205 pages.

Woodward, K.W. 1906. Forestry in Nova Scotia. J. Forestry 4:10-13.

Wright, R.F., T. Dale, E.T. Gjessing, G.R. Hendrey, A. Henriksen, M. Johannessen, and I.P. Muniz. 1975. Impact of acid precipitation on freshwater ecosystems in Norway. FR3/75, SNSF-project, 0s10. 16 pages. 
Wright, R.F. and H. Dovland. 1977. Regional surveys of the chemistry of the snowpack in Norway late winter 1973, 1974, 1975 and 1976. FR12/77, SNSFproject, 0slo. 29 pages.

Wright, R.F. and A. Henriksen. 1978. Chemistry of small Norwegian lakes, with special reference to acid precipitation. Limnol. Oceanogr. 23:487-498.

Wright, R.F. and M. Johannessen. 1980. Input-output budgets of major ions at gauged catchments in Norway, pp. 250-251. IN D. Drablos and A. Tollan [ed.] Ecological Impact of Acid Precipitation. SNSF-project, 0s70. 383 pages.

Yuan, W.L. and P.H. Hsu. 1971. Effect of foreign components on the precipitation of phosphate by aluminum, pp. 1-16. Reprint from Proc. Fifth Int. Water Poll. Res. Conf., San Francisco, CA.

Young, V.A. 1934. Plant distribution as influenced by soil heterogeneity in Cranberry Lake region of the Adirondack Mountains. Ecology 15:154-196.

Zundel, G. 1969. Hydration and Intermolecular Interaction. Academic Press. 310 pages. 
University of

Connecticut Libraries

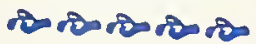



University of
Libraries

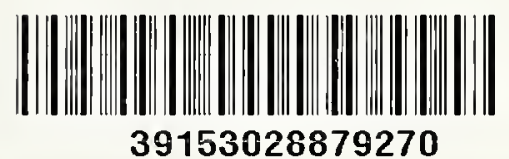

39153028879270 


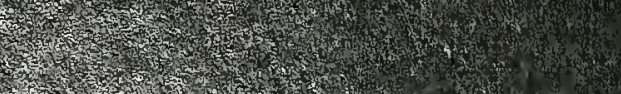

